\title{
Exposure to Sub-Lethal Doses of Permethrin Is Associated with Neurotoxicity: Changes in Bioenergetics, Redox Markers, Neuroinflammation and Morphology
}

\author{
Teresita Guadalupe López-Aceves ${ }^{1,2}$, Elvia Coballase-Urrutia ${ }^{2, * \mathbb{C}}$, Francisco Estrada-Rojo ${ }^{3}$ (), \\ América Vanoye-Carlo $^{2}$ D, Liliana Carmona-Aparicio ${ }^{2}$, María Eugenia Hernández ${ }^{4}\left(\mathbb{D}\right.$, José Pedraza-Chaverri ${ }^{5} \mathbb{D}$, \\ Luz Navarro ${ }^{3}$ D , Omar E. Aparicio-Trejo ${ }^{5}$ D, Armando Pérez-Torres ${ }^{6}$ D, Omar N. Medina-Campos ${ }^{5}$, \\ Daniel Martínez-Fong ${ }^{7}$, Vicente Sánchez-Valle ${ }^{8} \mathbb{D}$, Noemi Cárdenas-Rodríguez ${ }^{2} \mathbb{D}$, Leticia Granados-Rojas ${ }^{2}$, \\ Evelyn Pulido-Camarillo ${ }^{6}$, Verónica Rodríguez-Mata ${ }^{6}$ and Claudia del R. León-Sicairos ${ }^{1}$
}

1 Regional Graduate Program in Biotechnology, Faculty of Biological Chemical Sciences, Autonomous University of Sinaloa, Culiacán 80000, Mexico; tgla19@hotmail.com (T.G.L.-A.); claudialeonsicairos@uas.edu.mx (C.d.R.L.-S.)

2 Laboratory of Neuroscience, National Institute of Pediatrics, Mexico City 04530, Mexico; america_vc@yahoo.com.mx (A.V.-C.); c_apariccio@yahoo.com.mx (L.C.-A.);

check for

updates

Citation: López-Aceves, T.G.;

Coballase-Urrutia, E.; Estrada-Rojo, F.;

Vanoye-Carlo, A.;

Carmona-Aparicio, L.;

Hernández, M.E.;

Pedraza-Chaverri, J.; Navarro, L.;

Aparicio-Trejo, O.E.; Pérez-Torres, A.;

et al. Exposure to Sub-Lethal Doses of

Permethrin Is Associated with

Neurotoxicity: Changes in

Bioenergetics, Redox Markers,

Neuroinflammation and Morphology.

Toxics 2021, 9, 337. https://doi.org/

$10.3390 /$ toxics 9120337

Academic Editor: Jason R. Richardson

Received: 21 October 2021

Accepted: 23 November 2021

Published: 6 December 2021

Publisher's Note: MDPI stays neutral with regard to jurisdictional claims in published maps and institutional affiliations.

Copyright: (c) 2021 by the authors. Licensee MDPI, Basel, Switzerland. This article is an open access article distributed under the terms and conditions of the Creative Commons Attribution (CC BY) license (https:// creativecommons.org/licenses/by/ $4.0 /)$. noemicr2001@yahoo.com.mx (N.C.-R.); lgranados_2000@yahoo.com.mx (L.G.-R.)

3 Department of Physiology, Faculty of Medicine, National Autonomous University of Mexico, Mexico City 04510, Mexico; fesro@hotmail.com (F.E.-R.); navarroluz2002@yahoo.com.mx (L.N.)

4 Subdirection of Clinical Research, National Institute of Psychiatry, Mexico City 14370, Mexico; drosoph2001@yahoo.com.mx

5 Department of Biology, Faculty of Chemistry, National Autonomous University of Mexico, Mexico City 04150, Mexico; pedraza@unam.mx (J.P.-C.); emilianoaparicio91@gmail.com (O.E.A.-T.); omarnoelmedina@gmail.com (O.N.M.-C.)

6 Department of Cell and Tissue Biology, Faculty of Medicine, National Autonomous University of Mexico, Mexico City 04510, Mexico; armandop@unam.mx (A.P.-T.); elyn_21@live.com.mx (E.P.-C.); verohistologabct@hotmail.com (V.R.-M.)

7 Department of Physiology, Biophysics and Neurosciences, Center for Research and Advanced Studies, Mexico City 07360, Mexico; dmartine@fisio.cinvestav.mx

8 Neuroplasticity and Neurodegeneration Laboratory, Department of Pharmacology, Center for Research and Advanced Studies, Mexico City 07360, Mexico; vicente2779@hotmail.com

* Correspondence: elcoballase@yahoo.com.mx

Abstract: Permethrin (PERM) is a member of the class I family of synthetic pyrethroids. Human use has shown that it affects different systems, with wide health dysfunctions. Our aim was to determine bioenergetics, neuroinflammation and morphology changes, as redox markers after subacute exposure to PERM in rats. We used MDA determination, protein carbonyl assay, mitochondrial $\mathrm{O}_{2}$ consumption, expression of pro-inflammatory cytokines and a deep histopathological analysis of the hippocampus. PERM (150 mg/kg and $300 \mathrm{mg} / \mathrm{kg}$ body weight/day, o.v.) increased lipoperoxidation and carbonylated proteins in a dose-dependent manner in the brain regions. The activities of antioxidant enzymes glutathione peroxidase, reductase, S-transferase, catalase, and superoxide dismutase showed an increase in all the different brain areas, with dose-dependent effects in the cerebellum. Cytokine profiles (IL-1 $\beta$, IL- 6 and TNF- $\alpha$ ) increased in a dose-dependent manner in different brain tissues. Exposure to $150 \mathrm{mg} / \mathrm{kg}$ of permethrin induced degenerated and/or dead neurons in the rat hippocampus and induced mitochondrial uncoupling and reduction of oxidative phosphorylation and significantly decreased the respiratory parameters state 3-associated respiration in complex I and II. PERM exposure at low doses induces reactive oxygen species production and imbalance in the enzymatic antioxidant system, increases gene expression of pro-inflammatory interleukins, and could lead to cell damage mediated by mitochondrial functional impairment.

Keywords: permethrin; neurotoxicity; bioenergetics; neuroinflammation 


\section{Introduction}

The potential risks of exposure to different pesticides have been the subject of multiple investigations. Different studies reported their effects on physiology, which can lead to the development of chronic degenerative diseases with epidemiological impact [1-3]. The residues of these compounds have been reported in food, water, sea life, birds, and biological substrates such as different tissues and breast milk [4-8].

Pyrethroid pesticides are synthetic derivatives of natural pyrethrins obtained from the chrysanthemum flower Chrysanthemum cinerariefolium. Pyrethroids include 42 compounds divided into two types and originally were considered safe for humans and other animals [9]. These compounds have become first-line insecticides for the control of domestic pests. They often replace home and agricultural use of certain restricted or banned insecticides, such as organophosphates and organochlorine [9-12]. Due to the constant use of pyrethroids in agricultural activities and in homes, they constitute a danger due to their accumulation in solid food [13].

The use of type I pyrethroids has been associated with tremors of the whole body, aggressive behavior, hypersensitivity and ataxia [9,11-15]. Their mechanism of action is related to changes in sodium channel conformation during their opening and closing in neuronal membranes $[14,15]$. Conversely, type II pyrethroids can cause choreoathetosissalivation syndrome and motor dysfunction possibly due to effects on chloride channels, including $\gamma$-aminobutyric acid (GABA) receptors [14].

Permethrin (PERM) is a member of the family of synthetic class I pyrethroids. It is widely used in agriculture and residential homes, since it is found in household sprays, aerosols, insect repellents, pet shampoos and lotions. It is also used directly in humans, as a treatment to eradicate dermal parasites such as scabies and pediculosis (lice) [16-20]. PERM has been shown to affect the reproductive, skeletal, cardiovascular, immune and neuronal systems by generating cardiotoxicity, endocrine dysfunction, hepatotoxicity and cytotoxicity $[16,21-25]$.

PERM may enter the body by skin contact, inhalation or ingestion (water/food) and due to its lipophilicity, can pass through the blood-brain barrier at concentrations that might be neurotoxic. It has been reported that PERM acts on glia and neurons, decreases neurogenesis and causes a partial loss of neurons and mild inflammation. It increases proinflammatory cytokines, mainly Tumor Necrosis Factor-alpha (TNF- $\alpha$ ), and contributes to neuroinflammation underlying several neurodegenerative diseases. Using in vitro and animal models, studies of pyrethroid effects showed that it activates microglia and the release of proinflammatory cytokines, as well as chronic neuroinflammation [26]. In Gulf War veterans, it has been reported that pyrethroids alter the blood-brain barrier, allowing the entrance of pro-inflammatory cytokines into the circulating blood, where they can act on peripheral immune cells and induce immune modulation [22,27-30].

The brain is especially vulnerable to mitochondrial dysfunction because it requires more energy than any other organ in the body. In this process, reactive oxygen species (ROS) are produced by the electron transport system elements, particularly by complex I and, to a lesser extent, by complex III. Recent studies have shown that exposure to different permethrin concentrations can alter the function of mitochondria, with the consequent increase in oxidative stress and inflammatory processes $[27,28,30]$. PERM can adversely affect cognitive and mood function either directly or indirectly via reduced hippocampal neurogenesis [27-31]. In the present study, we evaluated neurotoxicity induced by subacute exposure to PERM in sublethal doses and its effects on the immune systems, bioenergetic redox and morphology of the brain using an animal model.

\section{Materials and Methods}

All the experimental procedures followed the guidelines of the Official Mexican Norm for the use and care of laboratory animals (NOM-062-ZOO-1999), as well as for the disposal of biological residues (NOM-087-ECOL-1995). Experimental procedures are part of project 060/2018, approved by the Institutional Committees of Research and of Laboratory Animal 
Use and Care. Institutional Committee of Research is registered at the NIH Office for Human Research Protection (http:/ / ohrp.cit.nih.gov/search (accessed on 31 July 2020) with number IRB00008064 on 16 January 2019.

\subsection{Drugs}

All reagents and chemicals were purchased from Sigma-Aldrich (St. Louis, MO, USA). Sodium pentobarbital was obtained from Pisabental ${ }^{\circledR}$, PiSA Agropecuaria (Guadalajara, Jalisco, Mexico). All analytical reagents and stains were purchased from J.T. Baker (Xalostoc, Estado de México, Mexico). All other chemicals used in this study were of reagent grade and were commercially available.

\subsection{Experimental Groups}

Male Wistar rats weighing 150-180 g (5-6 weeks old) were used. The animal-housing room was maintained under constant conditions of temperature $\left(21 \pm 1{ }^{\circ} \mathrm{C}\right)$, relative humidity (50-60\%) and lighting (12-h light/dark cycle). Filtered air ( $5 \mathrm{~mm}$ particles) was exchanged 18 times $/ \mathrm{h}$. Animals were provided with a standard commercial rat chow diet (Harlan Teklad Global diet 2018S sterilized, Harland Teklad, Madison, WI, USA), and reverse osmosis filtered water was used. Rats were divided into four groups: Group (1) Sham (manipulated animals, no administration); Group (2) Animals with vehicle treatment (corn oil $1 \mathrm{~mL} / \mathrm{kg}$ /weight); Group (3) Animals with $150 \mathrm{mg} / \mathrm{kg}$, orally/day of PERM + vehicle; Group (4) Animals with $300 \mathrm{mg} / \mathrm{kg}$, orally/day PERM + vehicle and treated every $24 \mathrm{~h}$ for 14 days. Forty-eight hours after the last dose of permethrin, all animals were anesthetized with pentobarbital $(0.6 \mu \mathrm{L} / \mathrm{kg}$, i.p.).

The brains (cerebellum, cortex, cerebral hemispheres and medulla) were immediately excised and stored at $-70{ }^{\circ} \mathrm{C}$ until analysis of antioxidant enzymes, protein carbonylation (PC) and lipid peroxidation, as well as pro-inflammatory cytokine expression by RT-PCR ( $n=6$ per group). In order to evaluate effects of PERM on bioenergetics, brain mitochondria were isolated and $\mathrm{O}_{2}$ consumption was measured.

\subsection{Permethrin Oral Exposure}

PERM was dissolved in corn oil and administered orally $(n=6)$ for 15 days, at daily doses of $150 \mathrm{mg} / \mathrm{kg}$ body weight per day (1/10 of LD50) and $300 \mathrm{mg} / \mathrm{kg}$ body weight/day (1/5 of LD50) [32]. The vehicle group received corn oil $(1 \mathrm{~mL} / \mathrm{kg}, n=12)$ for 15 days. The compounds were administered orally using an intragastric tube in the morning, and rats were not fasted overnight.

\subsection{Tissue Homogenization}

Tissues were homogenized in phosphate buffer $(0.1 \mathrm{M}, \mathrm{pH} 7.0)$ with $0.1 \%$ Triton X-100 using a Brinkmann Polytron model PT 2000 (Westbury, NY, USA) and centrifuged at 19,000 $\times g$ for $10 \mathrm{~min}$. The supernatant was used to quantify total protein concentration (Lowry method), evaluate lipoperoxidation (MDA), protein carbonyl content and the activity of antioxidant enzymes, such as superoxide dismutase (SOD), catalase (CAT), glutathione peroxidase (GPx), glutathione reductase (GR), and glutathione S-transferase (GST).

\subsection{Total Protein Quantitation by the Lowry Method}

Samples subjected to this colorimetric reaction were read in triplicate on a spectrophotometer (BioTek; Synergy HT) at $660 \mathrm{~nm}$. Protein quantification was performed using an 8-point standard curve of bovine serum albumin (BSA), which was used as a reference [33].

\subsection{Oxidative Stress Marker Detection}

Determination of MDA levels was performed as described by Coballase-Urrutia et al. (2010 and 2013) [34,35]. The activity of the antioxidant enzymes GR, SOD, CAT and GPx (all in $\mathrm{U} / \mathrm{mg}$ protein) and GST ( $\mu \mathrm{mol} \mathrm{CDNB}$ conjugate formed $/ \mathrm{min} / \mathrm{mg}$ protein) was measured. 


\subsection{Protein Carbonyl Assay}

Protein carbonyl content was analyzed using a PC ELISA kit (Enzo Life Sciences, Plymouth Meeting, PA, USA). Protein carbonyl levels were expressed as nM/mg of protein [36].

\subsection{Mitochondrial Isolation}

After animal sacrifice, the hippocampus was cooled to $4{ }^{\circ} \mathrm{C}$ by immersion in mitochondrial isolation buffer ( $225 \mathrm{mM}$ D-mannitol, $75 \mathrm{mM}$ sucrose, $1 \mathrm{mM}$, Ethylenediamine tetra acetic acid (EDTA), $5 \mathrm{mM}$, 4-(2-hydroxyethyl)-1-piperazineethanesulfonic acid (HEPES), $0.1 \% \mathrm{BSA}, \mathrm{pH}=7.4$ ) and cut into small pieces. The tissues were homogenized in a glass Potter-Elvehjem with a TeflonVR pestle using the same buffer, and mitochondria were obtained by differential centrifugation [37]. Briefly, homogenates were centrifuged at $2000 \times g$ for $5 \mathrm{~min}$, and the supernatants were centrifuged at 12,000 $\mathrm{g}$ for $15 \mathrm{~min}$, after which a wash was performed with BSA-free mitochondrial isolation buffer [38]. The final pellet was resuspended in $80 \mu \mathrm{L}$ of BSA-free mitochondrial isolation buffer and total mitochondrial proteins were estimated by the Lowry method [33].

\subsection{Mitochondrial $\mathrm{O}_{2}$ Consumption}

Mitochondrial $\mathrm{O}_{2}$ consumption was evaluated using high-resolution respirometry (oxygraph O2k, OROBOROS, Innsbruck, Austria) at $37^{\circ} \mathrm{C}$. Isolated mitochondria (300 $\mu \mathrm{g}$ of total protein) were loaded into a chamber with $2 \mathrm{~mL}$ of MiR05 respiration buffer: $0.5 \mathrm{mM}$ EGTA, $3 \mathrm{mM} \mathrm{MgCl}$, $60 \mathrm{mM}$ K-lactobionate, $20 \mathrm{mM}$ taurine, $10 \mathrm{mM} \mathrm{KH}_{2} \mathrm{PO}_{4}, 20 \mathrm{mM}$ HEPES, $110 \mathrm{mM}$ sucrose and $1 \mathrm{~g} / \mathrm{L}$ essentially fatty-acid free BSA. Electron transport was started by addition of complex I-linked substrates $(5 \mathrm{mM}$ sodium pyruvate and $2 \mathrm{mM}$ malate) or a complex II-linked substrate (10 $\mathrm{mM}$ succinate) plus a complex I inhibitor ( $0.5 \mu \mathrm{M}$ rotenone). State 3 (S3) was stimulated by the addition of $2 \mathrm{mM}$ ADP and $2.5 \mu \mathrm{M}$ oligomycin induced state 4 (S4o). All parameters were corrected by residual respiration (ROX), which was obtained by addition of $0.5 \mu \mathrm{M}$ rotenone plus $2.5 \mu \mathrm{M}$ antimycin A. The respiratory control index was defined as the S3/S4o ratio, and OXPHOS-associated respiration $(\mathrm{P})$ was defined as S3-S4o $[37,38]$. All reported values were normalized by total protein content estimated by the Lowry method [33].

\subsection{RT-PCR Expression for Pro-Inflammatory Cytokines}

Total RNA was isolated from 50-100 mg of frozen cerebellum, cerebral hemispheres, cortex and medulla by homogenization in Trizol TM (Invitrogen Corporation, Carlsbad, CA, USA) followed by chloroform-isopropanol extraction. RNA concentration was quantified using a NanoDrop (ND-1000 Spectrophotometer). RNA samples were treated with 1 U RNase-free DNase I (Invitrogen Life Technologies, Carlsbad, CA, USA) per $1 \mu \mathrm{g}$ of RNA. Total RNA was used for the generation of cDNA by retro-transcription (SuperScript IIITM First-Strand Synthesis System for RT-PCR, InvitrogenTM) using $3 \mu \mathrm{g}$ of total RNA and $0.1 \mathrm{mg}$ oligo dT (Invitrogen Corporation, Carlsbad, CA, USA). The design of oligonucleotides was performed with the IDT program SciTools Primer Quest YE (Integrated DNA Technologies, Inc. (c) Copyright 2012). The reverse-transcribed product (cDNA) was amplified by PCR in a final reaction volume of $25 \mu \mathrm{L}$ containing $2.5 \mu \mathrm{L}$ of $10 \times$ buffer, $0.75 \mu \mathrm{L}$ of $\mathrm{MgCl} 250 \mathrm{mM}, 0.5 \mu \mathrm{L}$ of the forward oligonucleotide and $0.5 \mu \mathrm{L}$ of the reverse oligonucleotide, $1.5 \mu \mathrm{L}$ of cDNA, $0.5 \mu \mathrm{L}$ of deoxyribonucleotide and $0.2 \mu \mathrm{L}$ of Taq-polymerase $(5 \mathrm{U} / \mu \mathrm{L})$. The PCR was performed using a thermocycler (Veriti ${ }^{\circledR}$ Thermal Cycler de Applied Biosystems) with an initial denaturation $\left(94^{\circ} \mathrm{C}, 5 \mathrm{~min}\right)$ followed by 30 cycles of denaturation $\left(94^{\circ} \mathrm{C}, 30 \mathrm{~s}\right.$ ), annealing (to align using corresponding $\mathrm{Tm}$ for $30 \mathrm{~s}$ ), extension $\left(72{ }^{\circ} \mathrm{C}, 20 \mathrm{~s}\right)$ and an additional denaturation $\left(72{ }^{\circ} \mathrm{C}, 1 \mathrm{~min}\right)$.

The PCR products were separated on a $2 \%$ agarose gel and stained with ethidium bromide. Photographs of the gels were taken with a Kodak EDAS 290 camera (Kodak Co.; Rochester, NY, USA). PCR data analysis was carried out by normalization to beta-actin as a control gene in triplicate, and the expression levels were calculated by normalizing relative expression values to the mean of the untreated control. The sequences for each 
gene were searched in the National Center for Biotechnology Information (NCBI) database (data shown in Table 1).

Table 1. Oligonucleotides for gene expression assessment. From left to right: gene name, gene bank oligonucleotide (pb), $\mathrm{TM}\left({ }^{\circ} \mathrm{C}\right)$, primer sequence, forward and reverse.

\begin{tabular}{cccccc}
\hline Gene Name & $\begin{array}{c}\text { GenBank } \\
\text { Accession No. }\end{array}$ & $\begin{array}{c}\text { Oligonucleotide } \\
(\mathbf{p b})\end{array}$ & Tm $\left({ }^{\circ} \mathbf{C}\right)$ & Forward & Reverse \\
\hline IL-1 $\beta$ & NM_031512.2 & 228 & 60 & $\begin{array}{c}\text { GATGTTCCCATTAG } \\
\text { ACAGCTGCAC }\end{array}$ & $\begin{array}{c}\text { GTCTTTCATCAC } \\
\text { ACAGGACAGG }\end{array}$ \\
\hline IL-6 & NM_012589.1 & 221 & 54 & $\begin{array}{c}\text { TGGAGTTCCGTTTCT } \\
\text { ACCTGGAGT }\end{array}$ & $\begin{array}{c}\text { TGGATGGTCTTGGTC } \\
\text { CTTAGCCA }\end{array}$ \\
\hline TNF- $\alpha$ & HQ201305.1 & 152 & 60 & $\begin{array}{c}\text { CTGGCCAATGGCATG } \\
\text { GATCTCAAA }\end{array}$ & $\begin{array}{c}\text { TGGTATGAAATGGCA } \\
\text { AACCGGCTG }\end{array}$ \\
\hline beta-actin & AF541940.1 & 217 & 60 & $\begin{array}{c}\text { CTGACAGGATGCA } \\
\text { GAAGGAGAT }\end{array}$ & $\begin{array}{c}\text { AGTAACAGTCCGC } \\
\text { CTAGAAGCA }\end{array}$ \\
\hline
\end{tabular}

\subsection{Hippocampal Histopathological Analysis}

Whole-body perfusion was performed in appropriately anesthetized rats (pentobarbital overdose) to fix the tissue. The pentobarbital overdose was administered in the experimental rats with $50 \mathrm{mg} / \mathrm{kg}$ i.p. of sodium pentobarbital (Pisabental ${ }^{\circledR}$ ). A gravity-fed perfusion apparatus was used with two bottles, one containing physiological solution and the other containing fixative solution; these were placed about $130 \mathrm{~cm}$ above the animal being perfused [39]. Blood was removed from the circulatory system with the physiological solution at room temperature (RT). Heparin was perfused in the left ventricle of the heart, with medical infusion equipment. A cut made in the right atrium allowing the exit of blood and saline solution for $20 \mathrm{~min}$. Paraformaldehyde $(4 \% v / v)$ in phosphate buffer $(0.1 \mathrm{M}$, $\mathrm{pH}$ 7.2) at RT was perfused for $20 \mathrm{~min}$. The rats were decapitated, and their brains were removed from the skull and immersed in the same fixative for $24 \mathrm{~h}$ at RT. After an overnight wash in tap water, the brains were manually sectioned with a blade, coronally at the bregma $-2.12 \mathrm{~mm}$ stereotaxic coordinate [40]. The specimens were then processed by paraffin embedding to obtain tissue sections ( $4 \mu \mathrm{m}$ thick) until the bregma $-3.03 \mathrm{~mm}$ coordinate. Sections were stained with hematoxylin \& eosin (HE) using the Klüver-Barrera method [41]. HE-stained sections were evaluated to detect necrotic neurons based on nuclear changes indicative of cell death such as pyknosis, karyolysis and karyorrhexis, attributable to the nonspecific breakdown of DNA. Furthermore, an increase in cytoplasmic eosinophilia was a histological manifestation of necrosis [42]. These histopathological findings were confirmed with the Klüver-Barrera method. Hippocampus of 6 animals per treatment were analyzed as follows. Three tissue sections $(4 \mu \mathrm{m})$ of medial hippocampus (Bregma 3.3) containing Cornu Ammonis CA1, CA2, CA3 fields, as well as the superior and inferior blade and hinge of the dentate gyrus (DG), were analyzed. HE-stained sections were evaluated to detect necrotic neurons based on nuclear changes indicative of cell death such as pyknosis, karyolysis and karyorrhexis, attributable to the nonspecific breakdown of DNA. Furthermore, an increase in cytoplasmic eosinophilia is a histological manifestation of necrosis [42]. These histopathological findings were confirmed with Klüver-Barrera method.

\subsection{Statistical Analysis}

The statistical analysis was performed using GraphPad Prism 6.0 for Windows (GraphPad Software, San Diego, CA, USA). Results were expressed as mean \pm standard deviations (mean $\pm \mathrm{SDM}$ ). Multiple comparisons were analyzed using one-way ANOVA followed by Bonferroni's multiple comparisons post-hoc tests. To evaluate mitochondrial $\mathrm{O}_{2}$ consumption, a one-way ANOVA was performed followed by a Tukey pos-hoc test. Values of $p<0.05$ were considered statistically significant. 


\section{Results}

\subsection{Permethrin Exposure Induces Lipoperoxidation and Carbonylation}

Lipoperoxidation and carbonylation were evaluated in the different brain areas of sham, vehicle (corn oil) and treated (150 or $300 \mathrm{mg} / \mathrm{kg}$ body weight permethrin) rats, after 15 days of treatment. The areas analyzed were cerebellum, cerebral cortex, cerebral hemispheres, and medulla (Table 2 and Figure 1). MDA values detected in the brain tissue of sham and vehicle groups were in the physiological range (baseline). PERM oral administration, at dose of $150 \mathrm{mg} / \mathrm{kg}$ body weight and $300 \mathrm{mg} / \mathrm{kg}$ body weight/day, increased lipoperoxidation in a dose-dependent manner in the brain regions analyzed (Table 2). The increase in lipoperoxidation after $150 \mathrm{mg} / \mathrm{kg}$ of permethrin exposure was $33.41 \%$ and $22.89 \%$ for the cerebellum and cortex, respectively, whereas for the cerebral hemispheres the increase was $69.88 \%$ and $59.73 \%$, respectively, in the medulla when compared to vehicle and sham conditions.

The oxidative effect of PERM on the different brain areas was more evident using the $300 \mathrm{mg} / \mathrm{kg}$ dose; an increase of $44.17 \%$ was observed in the cerebellum, $40.61 \%$ in the cortex, $72.16 \%$ in the medulla and almost $100 \%$ in cerebral hemispheres.

Table 2. Effect of permethrin exposure on lipoperoxidation of brain areas. MDA (nmoles $/ \mathrm{mL} / \mathrm{mg}$ of protein) levels in the different brain regions (cerebellum, cerebral cortex, cerebral hemispheres and medulla) of animals treated with permethrin (PERM 150 and $300 \mathrm{mg} / \mathrm{kg}$ ) are shown as percentages (mean $\pm \mathrm{SD}$ ) of the levels detected in the vehicle and sham groups.

\begin{tabular}{|c|c|c|c|c|}
\hline Groups & Cerebellum & Cerebral Cortex & Cerebral Hemispheres & Medulla \\
\hline Sham & $60.90 \pm 1.89$ & $69.53 \pm 5.02$ & $50.3 \pm 3.28$ & $40.63 \pm 3.81$ \\
\hline Corn oil (CO) & $69.83 \pm 5.11^{\mathrm{ns}}$ & $72.53 \pm 4.72^{\mathrm{ns}}$ & $51.24 \pm 4.7^{\mathrm{ns}}$ & $48.34 \pm 3.76^{\mathrm{ns}}$ \\
\hline PERM 150 & $81.25 \pm 5.43^{* *}$ & $85.45 \pm 6.56^{*}$ & $85.45 \pm 6.56^{* *}$ & $64.90 \pm 7.77^{* *}$ \\
\hline PERM 300 & $87.80 \pm 4.88^{* *}$ & $97.77 \pm 8.49^{* *}$ & $97.77 \pm 8.49^{* * *}$ & $69.95 \pm 4.06^{* * *}$ \\
\hline
\end{tabular}

Effect of PERM on the cerebellum, prefrontal cortex, cerebral hemispheres and medulla among all groups. Without statistically different is showed as ns. It was statistically different between conditions: cerebellum. $\mathrm{F}(3,8)=12.76,{ }^{*} p<0.002$; vs. sham; prefrontal cortex $\mathrm{F}(3,8)$ $=19.16,{ }^{*} p<0.0005$ vs. sham and ${ }^{* *} p<0.002$ vs. sham; cerebral hemispheres $\mathrm{F}(3,8)=12.76,{ }^{* *} p<0.002$ vs. sham and ${ }^{* * *} p<0.001$ vs. sham and medulla $\mathrm{F}(3,8)=18.32$, ${ }^{* *} p<0.0005$ vs. sham and ${ }^{* * *} p<0.0006$ vs. sham. Each quantification was performed in triplicate using samples from six rats, and the values represent the mean $\pm \mathrm{SD}$. The differences were analyzed using ANOVAs followed by Bonferroni tests.

In the four brain regions analyzed (cerebellum, cerebral cortex, cerebral hemispheres, and medulla) of the sham group, PC levels were low and considered as physiological values (Figure 1). On the other hand, carbonylated proteins detected in brain areas of animals treated with PERM showed an important increase compared to basal conditions. PERM treatment triggered a 37.47 and $20.80 \%$ increase in carbonylated proteins in the cerebellum with $150 \mathrm{mg} / \mathrm{kg}$ and $300 \mathrm{mg} / \mathrm{kg}$, respectively $\left(\mathrm{F}(3,8)=29.61,{ }^{*} p<0.0001\right)$. For the cerebral cortex, the increase reached almost $100 \%$ with the $150 \mathrm{mg} / \mathrm{kg}$ dose and $84.6 \%$ with $300 \mathrm{mg} / \mathrm{kg}(\mathrm{F}(3,8)=21.06, * p<0.0001)$. In the cerebral hemispheres, increases of $18.98 \%$ and $21.12 \%$ were observed $\left(\mathrm{F}(3,8)=19.26,{ }^{*} p<0.0001\right)$, and in the medulla, the increase was $28.0 \%$ and $50.56 \%$ with $150 \mathrm{mg} / \mathrm{kg}$ and $300 \mathrm{mg} / \mathrm{kg}$, respectively $(\mathrm{F}(3,8)=8.20, * p<0.001$, Figure 1$)$. 

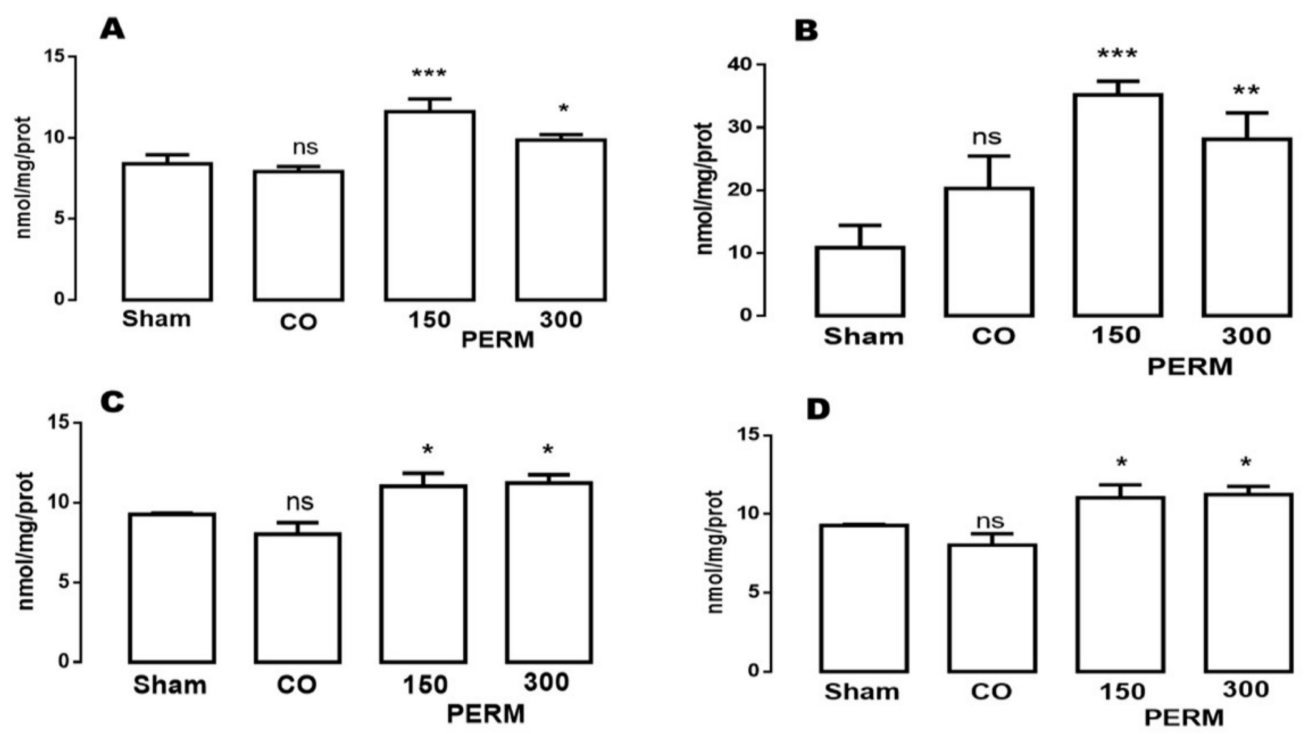

Figure 1. Effect of permethrin on protein carbonyl content in different tissues of the brain: (A) cerebellum; (B) cerebral cortex; (C) cerebral hemispheres; (D) medulla; at dose of 150 (1/10 of LD50) and $300 \mathrm{mg} / \mathrm{kg}$ body weight/day (1/5 of LD50). Corn oil (CO) was administered as vehicle $(1 \mathrm{~mL} / \mathrm{kg} /$ day) for 15 days. The results were analyzed by ANOVAs; Bonferroni's multiple comparisons test was used to compare the outcomes between the experimental, vehicle and sham groups. Mean \pm standard deviations ( $n=6$ per group). Without statistically different is showed as ns. ${ }^{* * *} p<0.0001$ vs. sham group; ${ }^{* *} p<0.001$ vs. sham group, ${ }^{*} p<0.01$ vs. sham group; ns (not significant). CO: Corn oil, PERM: Permethrin.

\subsection{Antioxidant Marker Determination}

To deepen understanding of the mechanism of PERM-induced damage, GPx, GR, CAT, SOD and GST activities were evaluated in different brain regions, in consideration that these enzymes are the brain natural antioxidant system. PERM administration in different concentrations increased the activity of almost all the antioxidant enzymes explored in the different regions of the brain (cerebellum, cerebral cortex, cerebral hemispheres and medulla). The levels of activity of antioxidant enzymes in the brain regions of sham and corn oil treatment animals were similar and considered as physiological values (Table 3).

Table 3. Effect of permethrin (150 and $300 \mathrm{mg} / \mathrm{kg}$ body weight/day) on the activity of antioxidant enzymes in different brain tissues.

\begin{tabular}{|c|c|c|c|c|c|}
\hline Treatment & $\begin{array}{c}\text { GPx } \\
\text { (U/mg/Prot) }\end{array}$ & $\begin{array}{c}\text { GR } \\
\text { (U/mg/Prot) }\end{array}$ & $\begin{array}{c}\text { CAT } \\
\text { (U/mg/Prot) }\end{array}$ & $\begin{array}{c}\text { SOD } \\
\text { (U/mg/Prot) }\end{array}$ & $\begin{array}{c}\text { GST } \\
(\mu \mathrm{mol} / \mathrm{CDNBmin} / \text { Prot })\end{array}$ \\
\hline \multicolumn{6}{|l|}{ Cerebellum } \\
\hline Sham & $0.019 \pm 0.001$ & $0.013 \pm 0.001$ & $8.90 \pm 0.36$ & $2.11 \pm 0.171$ & $0.036 \pm 0.006$ \\
\hline Corn oil & $0.020 \pm 0.002^{\mathrm{ns}}$ & $0.014 \pm 0.002^{\mathrm{ns}}$ & $11.24 \pm 0.81^{\mathrm{ns}}$ & $3.06 \pm 0.226^{*}$ & $0.039 \pm 0.016^{\mathrm{ns}}$ \\
\hline PERM 150 mg/kg & $0.026 \pm 0.003 *$ & $0.019 \pm 0.003 *$ & $13.96 \pm 0.74^{*}$ & $3.88 \pm 0.594^{* *}$ & $0.054 \pm 0.005^{\mathrm{ns}}$ \\
\hline PERM 300 mg/kg & $0.029 \pm 0.004^{* *}$ & $0.021 \pm 0.002 * *$ & $15.48 \pm 1.05^{* *}$ & $3.92 \pm 0.367^{* * *}$ & $0.068 \pm 0.005^{* *}$ \\
\hline \multicolumn{6}{|l|}{ Prefrontal cortex } \\
\hline Sham & $0.012 \pm 0.006$ & $0.015 \pm 0.006$ & $13.50 \pm 0.71$ & $1.19 \pm 0.052$ & $0.021 \pm 0.001$ \\
\hline Corn oil & $0.015 \pm 0.001^{\mathrm{ns}}$ & $0.010 \pm 0.001^{\mathrm{ns}}$ & $14.03 \pm 0.88^{\mathrm{ns}}$ & $1.23 \pm 0.14^{\mathrm{ns}}$ & $0.027 \pm 0.003^{\mathrm{ns}}$ \\
\hline PERM 150 mg/kg & $0.017 \pm 0.009^{* *}$ & $0.015 \pm 0.001^{\mathrm{ns}}$ & $17.98 \pm 1.30^{* *}$ & $1.86 \pm 0.14^{* * *}$ & $0.032 \pm 0.004^{* *}$ \\
\hline PERM 300 mg/kg & $0.016 \pm 0.0011^{\mathrm{ns}}$ & $0.014 \pm 0.002^{\mathrm{ns}}$ & $16.66 \pm 1.34$ * & $1.73 \pm 0.14^{* *}$ & $0.033 \pm 0.004^{* *}$ \\
\hline \multicolumn{6}{|l|}{$\begin{array}{c}\text { Cerebral } \\
\text { hemispheres }\end{array}$} \\
\hline Sham & $0.012 \pm 0.001$ & $0.010 \pm 0.000$ & $7.24 \pm 0.06$ & $0.86 \pm 0.005$ & $0.020 \pm 0.003$ \\
\hline
\end{tabular}


Table 3. Cont.

\begin{tabular}{|c|c|c|c|c|c|}
\hline Treatment & $\begin{array}{c}\text { GPx } \\
\text { (U/mg/Prot) }\end{array}$ & $\begin{array}{c}\text { GR } \\
\text { (U/mg/Prot) }\end{array}$ & $\begin{array}{c}\text { CAT } \\
\text { (U/mg/Prot) }\end{array}$ & $\begin{array}{c}\text { SOD } \\
\text { (U/mg/Prot) }\end{array}$ & $\begin{array}{c}\text { GST } \\
(\mu \mathrm{mol} / \mathrm{CDNBmin} / \text { Prot })\end{array}$ \\
\hline Corn oil & $0.013 \pm 0.001^{\mathrm{ns}}$ & $0.010 \pm 0.0011^{\mathrm{ns}}$ & $7.75 \pm 0.65^{\mathrm{ns}}$ & $0.97 \pm 0.144^{*}$ & $0.022 \pm 0.002^{\mathrm{ns}}$ \\
\hline PERM 150 mg/kg & $0.015 \pm 0.002 *$ & $0.010 \pm 0.001^{\mathrm{ns}}$ & $10.80 \pm 0.84^{*}$ & $1.09 \pm 0.045^{* *}$ & $0.029 \pm 0.001 \mathrm{~ns}$ \\
\hline PERM 300 mg/kg & $0.016 \pm 0.001 * *$ & $0.010 \pm 0.001^{\mathrm{ns}}$ & $10.76 \pm 0.73^{*}$ & $1.12 \pm 0.0640 *$ & $0.029 \pm 0.002^{\mathrm{ns}}$ \\
\hline \multicolumn{6}{|l|}{ Medulla } \\
\hline Sham & $0.022 \pm 0.000$ & $0.062 \pm 0.003$ & $9.97 \pm 0.75$ & $3.78 \pm 0.66$ & $0.021 \pm 0.001$ \\
\hline Corn oil & $0.021 \pm 0.0011^{\mathrm{ns}}$ & $0.070 \pm 0.001^{\mathrm{ns}}$ & $11.07 \pm 0.90^{\mathrm{ns}}$ & $4.98 \pm 0.98^{\mathrm{ns}}$ & $0.018 \pm 0.004^{\mathrm{ns}}$ \\
\hline PERM $150 \mathrm{mg} / \mathrm{kg}$ & $0.025 \pm 0.002^{\mathrm{ns}}$ & $0.076 \pm 0.00 *$ & $12.39 \pm 0.91 *$ & $6.72 \pm 1.4^{*}$ & $0.020 \pm 0.003^{\mathrm{ns}}$ \\
\hline PER 300 mg/kg & $0.025 \pm 0.002^{\mathrm{ns}}$ & $0.080 \pm 0.001 * *$ & $12.88 \pm 0.99^{* *}$ & $7.7 \pm 1.00 * *$ & $0.018 \pm 0.003^{\mathrm{ns}}$ \\
\hline
\end{tabular}

The results were analyzed with ANOVAs; Bonferroni's multiple comparison test was used to compare the outcomes between the experimental and Sham groups. Mean \pm standard deviations ( $n=6$ per group). Without statistically different is showed as ns. ${ }^{* *} p<$ 0.0001 vs. sham group; ${ }^{* *} p<0.001$ vs. sham group, ${ }^{*} p<0.01$ vs. sham group; CO: Corn oil, CAT: Catalase, GPx: Glutathione peroxidase, GR: Glutathione reductase, SOD: Superoxide dismutase (all in U/mg protein), GST: Glutathione-S-transferase (Umol/CDNB conjugate formed/min/mg protein) and PERM: Permethrin.

The activity of GPx increased after administration of both PERM doses (150 and $300 \mathrm{mg} / \mathrm{kg}$ ). The percentages of increase when compared to sham values were: in the cerebellum, 36.84\% and 52.63\%, respectively $(\mathrm{F}(3,8)=10,26, p<0.001)$; prefrontal cortex, $41.66 \%$ and $33.33 \%$, respectively $(\mathrm{F}(3,8)=7.42, p<0.01)$; cerebral hemispheres, $24.0 \%$ and $33.0 \%$, respectively $(\mathrm{F}(3,8)=7.96, p<0.001)$; and in the medulla, a lower increase of $13.63 \%$ with both doses was detected $(\mathrm{F}(3,8)=3.26, p<0.001)$.

The activity of GR also increased with both PERM doses used (150 and $300 \mathrm{mg} / \mathrm{kg}$ ) but was significant only in the cerebellum $(46.15 \%$ and $61.53 \%$, respectively; $\mathrm{F}(3,8)=7.24$, $p<0.01)$ and medulla $(22.58 \%$ and $29.03 \%$, respectively; $\mathrm{F}(3,8)=9.81, p<0.01)$. In the prefrontal cortex and cerebral hemispheres, the changes in activity were not significant.

For CAT activity, a dose-dependent effect was observed in the cerebellum and medulla, where the increase in enzyme activity was 56.85 and $24.27 \%$ for $150 \mathrm{mg} / \mathrm{kg}$ PERM $(\mathrm{F}(3,8)=7.36, p<0.01)$ and $73.93 \%$ and $29.18 \%$ for $300 \mathrm{mg} / \mathrm{kg}(\mathrm{F}(3,8)=8.05, p<0.001)$. On the other hand, the higher PERM dose $(300 \mathrm{mg} / \mathrm{kg})$ induced a lower increase in CAT activity compared to the lower dose $(150 \mathrm{mg} / \mathrm{kg})$ in the prefrontal cortex $(33.18 \%$ and $23.40 \%$, respectively; $\mathrm{F}(3,8)=11.38, p<0.01)$ and in the cerebral hemispheres $(49.17$ and $48.6 \%$, respectively; $\mathrm{F}(3,8)=7.06, p<0.01)$.

The changes in SOD activity were the highest for both doses of PERM. In cerebellum the increases in SOD activity were $83.88 \%$ for $150 \mathrm{mg} / \mathrm{kg}$ and $85.78 \%$ for $300 \mathrm{mg} / \mathrm{kg}$ $(\mathrm{F}(3,8)=15.86, p<0.001)$. In the prefrontal cortex, SOD activity was $56.30 \%$ and $45.37 \%$ higher when compared to basal conditions $(\mathrm{F}(3,8)=11.38, p<0.001)$. For the cerebral hemispheres, the increase was lower than in other brain areas $(26.74 \%$ and $30.23 \% ; \mathrm{F}(3,8)=8.44$, $p<0.001)$, and in the medulla, it was $77.77 \%$ and $100 \%$.

GST activity in the cerebellum showed an increase of 50.0 and $88.0 \%$ for 150 and $300 \mathrm{mg} / \mathrm{kg}$ of PERM, respectively, compared to sham values $(\mathrm{F}(3,8)=7.65, p<0.0001)$. In the prefrontal cortex, the increase was $52.0 \%$ and $57.0 \%$, respectively $(\mathrm{F}(3,8)=9.07$, $p<0.0001)$. In the cerebral hemispheres, GST activity was $45 \%$ higher with both doses, while in the medulla there were no significant changes.

\subsection{Permethrin Stimulates Cytokine Gene Expression}

PERM exposure is related to the development of degenerative diseases, and proinflammatory cytokines have been found to be involved in their physiopathology. Thus, we assessed if PERM treatment changed cytokine profiles in the different brain tissues studied (cerebellum, cerebral cortex, cerebral hemispheres and medulla). IL-1 $\beta$, IL-6 and TNF- $\alpha$ 
gene expression were analyzed by RT-PCR using the beta-actin gene for normalization (Figures 2-4).

IL-1 $\beta$ gene expression increased significantly after PERM exposure at both concentrations in all brain regions analyzed (cerebellum, cerebral cortex, cerebral hemispheres and medulla) compared to control values (sham and corn oil, which were not significantly different; Figure 2). The biggest changes in IL-1 $\beta$ were found in the cerebellum and medulla, with an increase of $192.62 \%$ and $217.79 \%$, respectively, after $150 \mathrm{mg} / \mathrm{kg}$ PERM $(\mathrm{F}(3,8)=49.79, p<0.0001)$ and $485.25 \%$ and $480.5 \%$, respectively, for $300 \mathrm{mg} / \mathrm{kg}$ PERM $(\mathrm{F}(3,8)=77.19, p<0.0001)$. For the cerebral cortex and cerebral hemispheres, levels of IL-1 $\beta$ expression reached $160.06 \%$ and $158.52 \%$, respectively, compared to control values with $150 \mathrm{mg} / \mathrm{kg}$ PERM $(\mathrm{F}(3,8)=67.53, p<0.0001)$ and $158.52 \%$ and $283.52 \%$, respectively, with the higher dose $(\mathrm{F}(3,8)=57.87, p<0.0001)$.

A
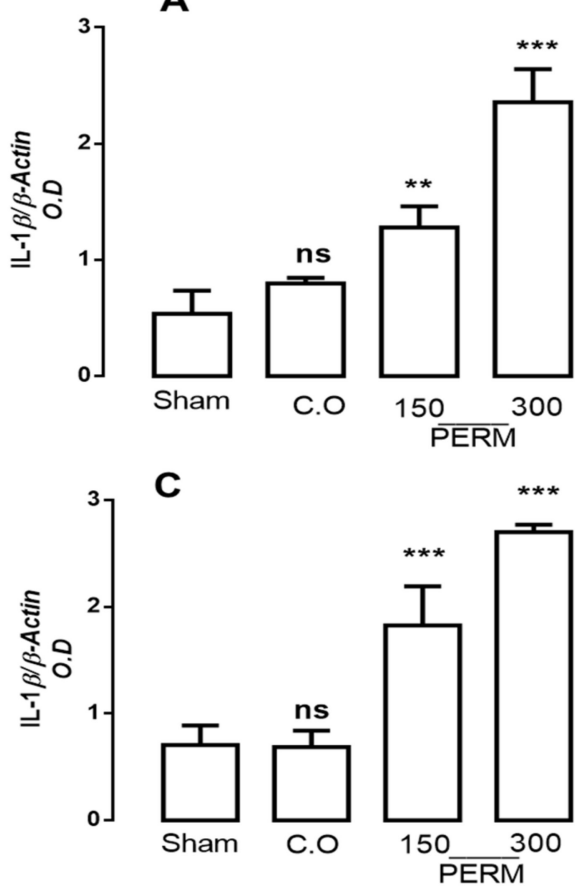

B

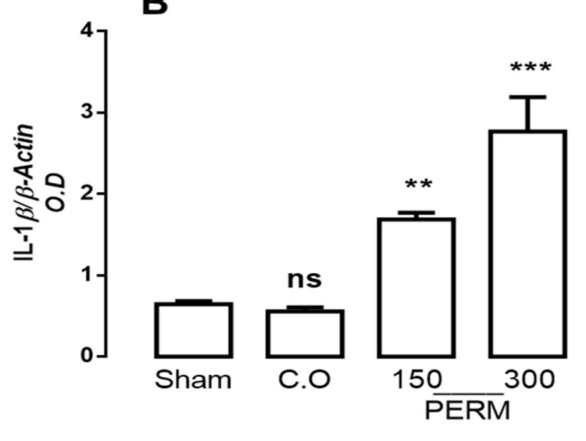

D

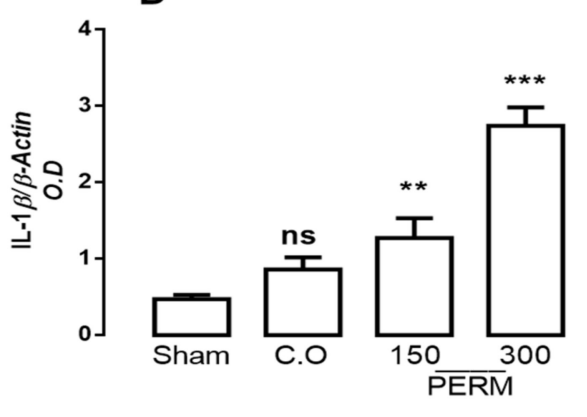

Figure 2. mRNA expression for IL-1 $\beta$ in the cerebellum (A), cerebral cortex (B), cerebral hemispheres (C) and medulla (D) in rats treated with corn oil (control group), permethrin $150 \mathrm{mg} / \mathrm{kg}$ or $300 \mathrm{mg} / \mathrm{kg}$, and rats without treatment (sham group). Values are mean $\pm \mathrm{SD}$ ( $n=4$ for each group). The results were analyzed with ANOVAs followed by Bonferroni's multiple comparisons tests to compare permethrin (150 or $300 \mathrm{mg} / \mathrm{kg}$ ) groups versus the control group (sham). Data from 6 independent experiments run in quadruplicate. Without statistically different is showed as ns. ${ }^{* *} p<0.001$ vs. sham group; and ${ }^{* * *} p<0.0001$ vs. sham group; CO (Corn oil); PERM (permethrin).

IL-6 expression levels showed an important increase compared to basal conditions in the cerebellum, cerebral cortex and medulla after $150 \mathrm{mg} / \mathrm{kg}$ PERM $(62.93,135.64$ and $244.28 \%$ respectively), while the increase after $300 \mathrm{mg} / \mathrm{kg}$ PERM was significant in all areas (166.4-287.28\%; Figure 3; cerebellum: $\mathrm{F}(3,8)=37.69, p<0.001$; cerebral cortex: $\mathrm{F}(3,8)=14.94, p<0.001$; cerebral hemispheres: $\mathrm{F}(3,8)=11.14, p<0.001$; medulla: $\mathrm{F}(3,8)=186.1, p<0.0001)$. No significant differences were found between the sham and $\mathrm{CO}$ groups.

TNF- $\alpha$ expression showed significant increases in all regions after PERM exposure at both concentrations. The greatest change was observed in cerebellum, where the increase in gene expression was 146.27 and $147.63 \%$ after 150 and $300 \mathrm{mg} / \mathrm{kg}$ permethrin, respectively (Figure $4 \mathrm{~A} ; \mathrm{F}(3,8)=150.6, p<0.001)$. In the other areas, slight changes were observed: cerebral cortex $(77.01 \%$ and $108.0 \%$, respectively; $\mathrm{F}(3,8)=39.15, p<0.0001)$, cerebral 
hemispheres $(78.09 \%$ and $112.38 \%$, respectively; $\mathrm{F}(3,8)=16.47, p<0.0001)$ and medulla $(15.78 \%$ and $24.56 \%$, respectively; $\mathrm{F}(3,8)=22.63, p<0.001)$. No significant differences were found between the sham and control groups.
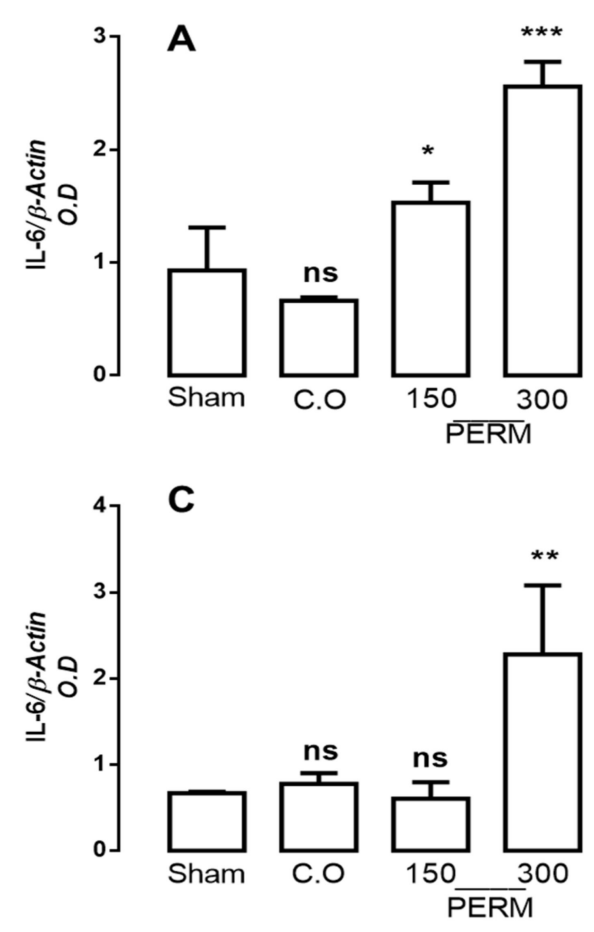

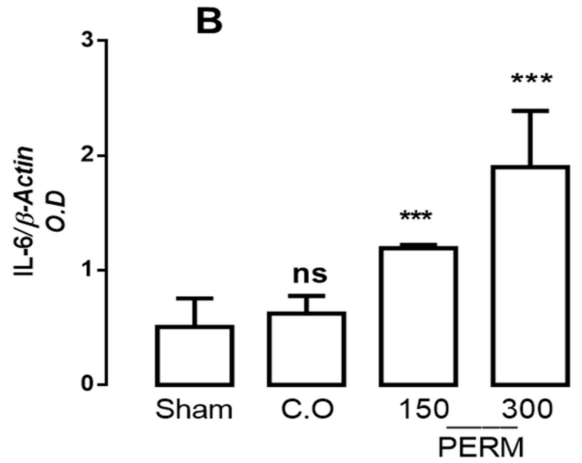

D

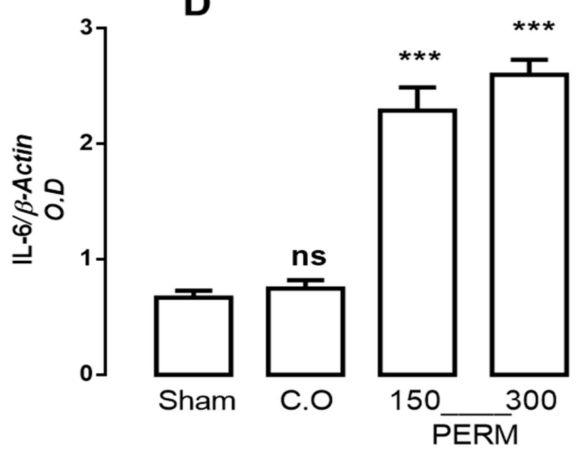

Figure 3. mRNA expression for IL-6 in the cerebellum (A), cerebral cortex (B), cerebral hemispheres (C) and medulla (D) in rats treated with corn oil (control group), permethrin $150 \mathrm{mg} / \mathrm{kg}$ or $300 \mathrm{mg} / \mathrm{kg}$ and rats without treatment (sham group). Values are mean $\pm \mathrm{SD}$ ( $n=4$ for each group). The results were analyzed with ANOVAs followed by Bonferroni's multiple comparisons tests to compare permethrin (150 or $300 \mathrm{mg} / \mathrm{kg}$ ) groups versus the control group (sham). Data from 6 independent experiments run in quadruplicate. Without statistically different is showed as ns. ${ }^{*} p<0.05 \mathrm{vs}$. sham group, ${ }^{* *} p<0.001$ vs. sham group; and ${ }^{* * *} p<0.0001$ vs. sham group; CO (Corn oil); PERM (permethrin).
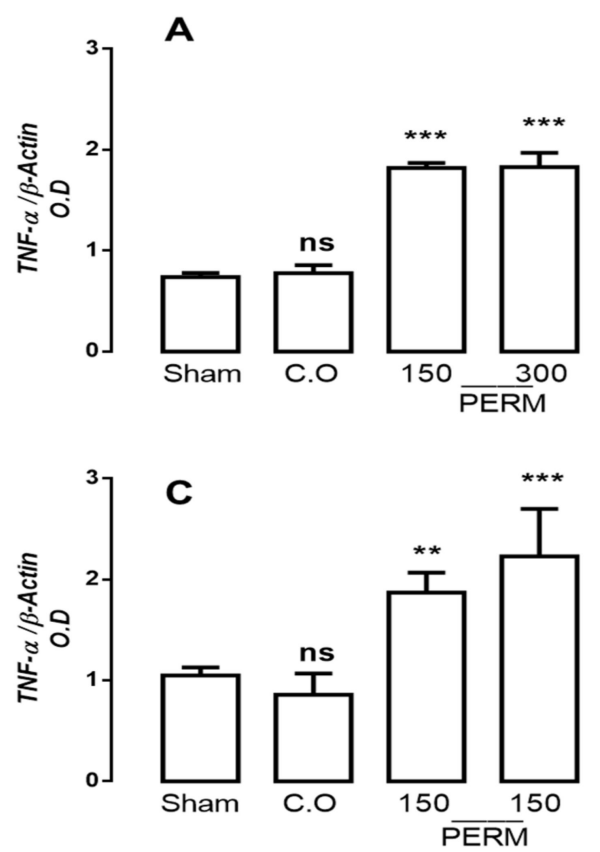

B
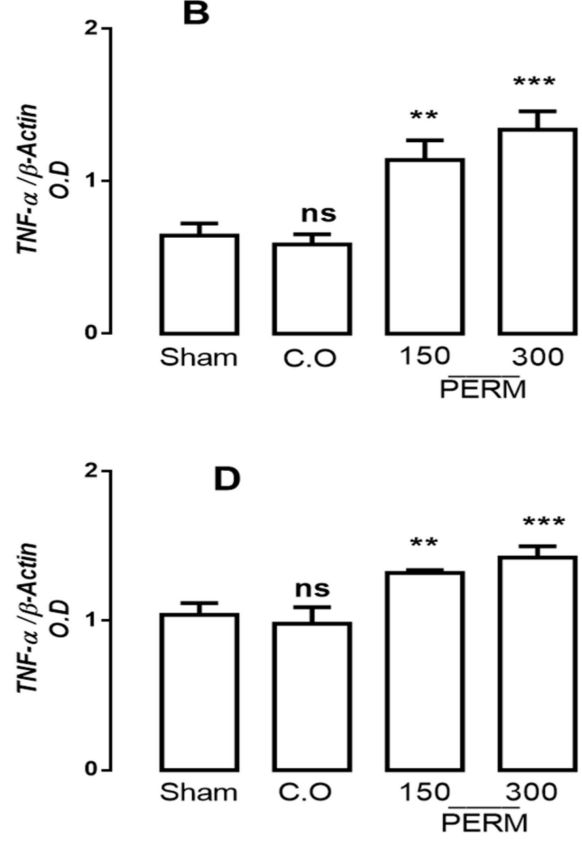

Figure 4. mRNA expression for TNF $\alpha$ in the cerebellum (A), cerebral cortex (B), cerebral hemispheres (C) and medulla (D) 
in rats treated with corn oil (control group), permethrin $150 \mathrm{mg} / \mathrm{kg}$ or $300 \mathrm{mg} / \mathrm{kg}$ and rats without treatment (sham group). Values are mean $\pm \mathrm{SD}$ ( $n=4$ for each group). The results were analyzed with ANOVAs followed by Bonferroni's post-hoc tests to compare permethrin (150 or $300 \mathrm{mg} / \mathrm{kg}$ ) groups versus the control group (corn oil). Mean \pm SD of 6 independent experiment run in quadruplicate. Without statistically different is showed as ns. ${ }^{* *} p<0.001$ vs. sham group; and *** $p<0.0001$ vs. sham group; CO (Corn oil); PERM (permethrin).

\subsection{Histopathological Analysis}

The previous data showed an effect on the brain, even using the low dose of permethrin $(150 \mathrm{mg} / \mathrm{kg})$. We explored brain damage by histopathological techniques using the lower dose employed in this study. The degenerated and/or dead neurons, identified by cell body contraction, pyknotic cones as well as nuclei with karyorrhexis and karyolysis increased in different areas of the rat hippocampus (CA1, CA2, CA3 and DG) after exposure to permethrin $(150 \mathrm{mg} / \mathrm{kg}$ ) (Figure 5). The cytoplasm of dead neurons showed the loss of Nissl granules (consisting of rough endoplasmic reticulum and polyribosomes), which is easily observed with the Klüver-Barrera (BK) stain. The perikaryon of degenerated or dead neurons stained turquoise blue (Figures 5 and 6 black arrows). These findings correlate with HE-stained hippocampal tissue sections (data not shown). The neuropil (area between glial and neuronal cell bodies that is made up of dendrites, axons, glial cells and microvasculature) changed its tinctorial affinity. In photomicrographs of the superior lamina (SB-DG), hinge region (H-DG) and inferior lamina (IB-DG) of the dentate gyrus of the hippocampus, an increase in degenerated cells was not observed when compared with the CO group (Figure 6).

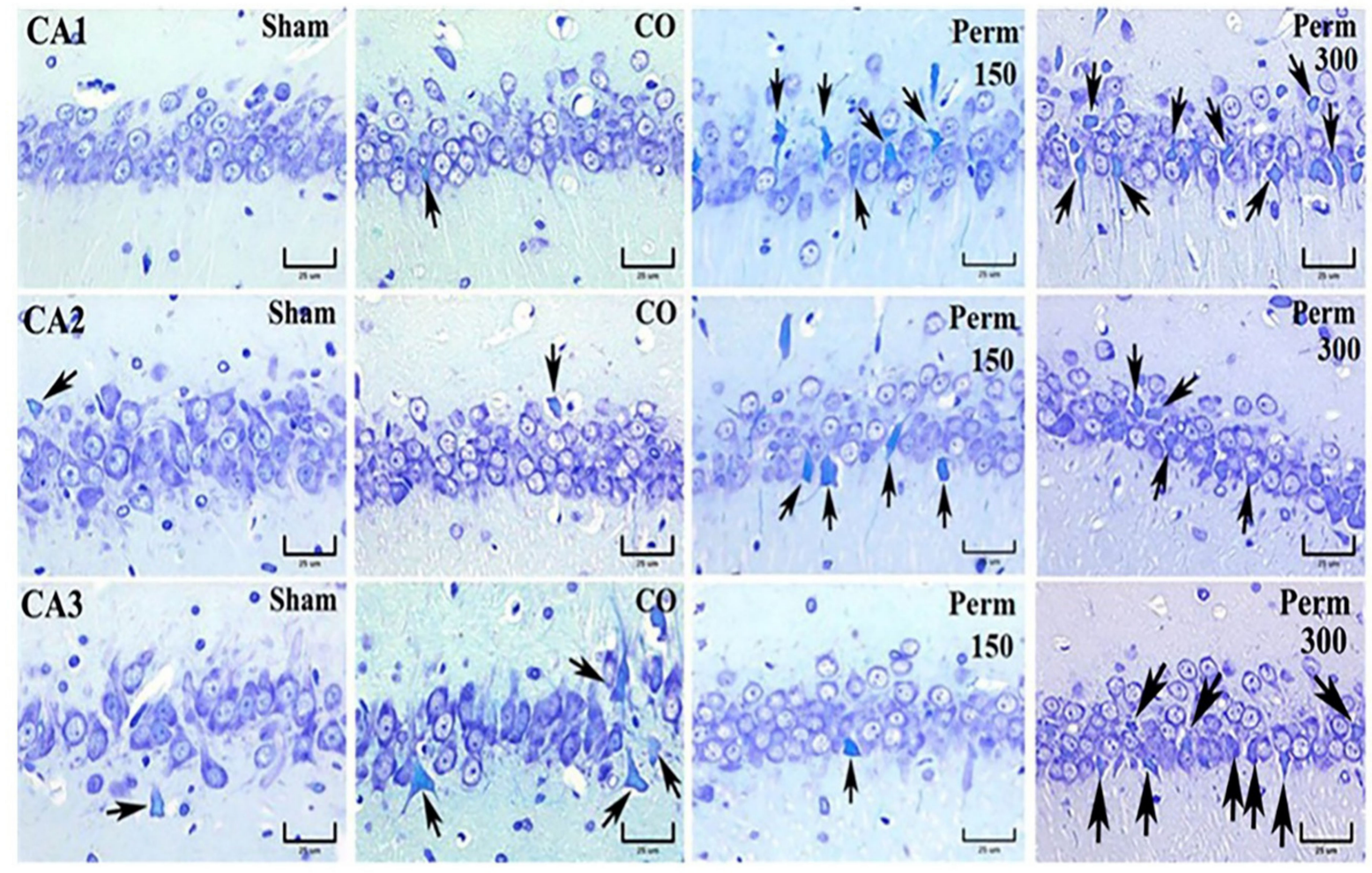

Figure 5. Photomicrographs of the hippocampal CA1, CA2 and CA3 of sham rats, rats treated with corn oil (CO) and rats treated with 150 and $300 \mathrm{mg} / \mathrm{kg}$ of permethrin. Arrows indicate neurons with histopathological features of cell degeneration or death. Klüver-Barrera stain. 

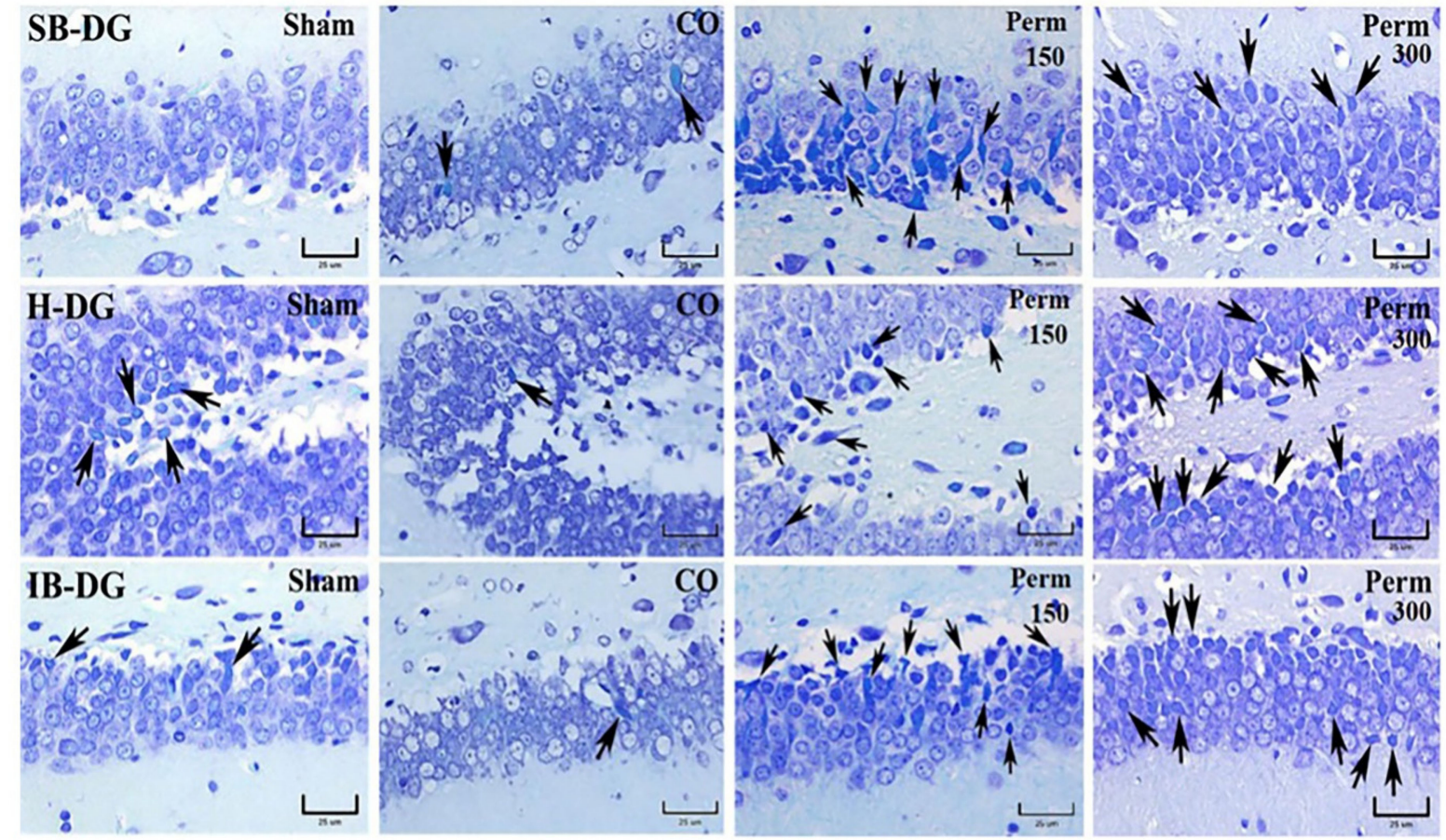

Figure 6. Photomicrographs of the superior lamina (SB-DG), hinge region (H-DG) and the inferior lamina (IB-DG) of the hippocampal dentate gyrus of rats with or without treatment. Arrows indicate neurons with histopathological features of cell degeneration or death by Klüver-Barrera stain.

\subsection{Permethrin Exposure Alters Mitochondrial Function}

To explore if hippocampal damage due to PERM is related to alterations in mitochondrial bioenergetics, we evaluated hippocampal mitochondrial respiratory parameters in CI- and CII-linked respiration (Figures 7 and 8). PERM induced mitochondrial uncoupling and reduction of oxidative phosphorylation (OXPHOS) determined by $p$ values. PERM significantly decreased the S3 and P respiratory parameters in $\mathrm{CI}$ and CII-linked respiration, starting at the lower dose. However, only the higher dose significantly reduced the RCI index of CII-linked respiration. Furthermore, the reduction in respiratory parameters was notably higher for CI-linked respiration.

These bioenergetics alterations suggest that PERM induced mitochondrial decoupling and a reduction of OXPHOS capacity, independently of the substrate type. Mitochondrial alterations could be related to a reduction in ATP synthase activity; however, taking into account the stronger effect in the respiration feed by PM, the results suggested that mitochondrial CI could be more affected. However, more experiments are needed to clarify this. 


\section{PM}

S3

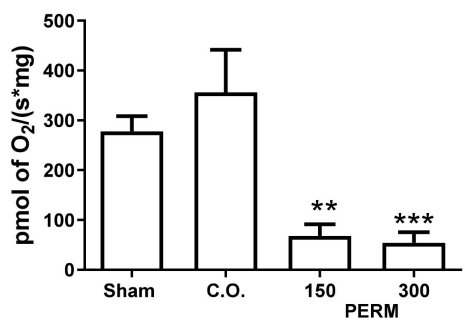

$\mathbf{P}$

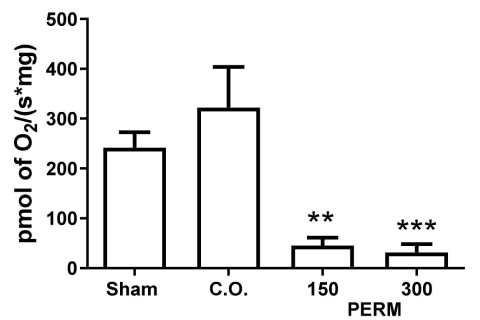

S40

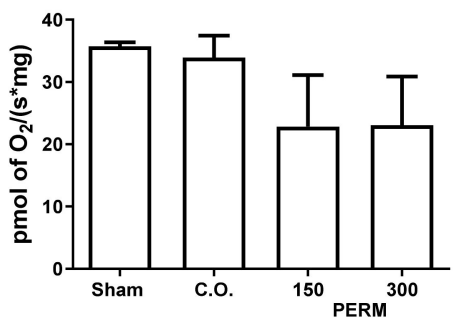

$\mathrm{RCI}$

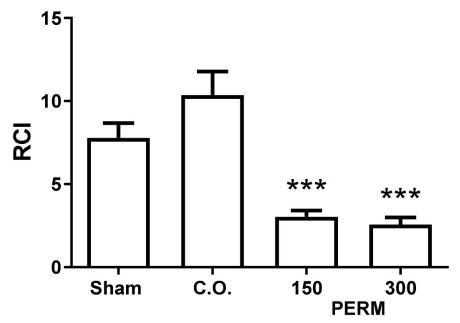

Figure 7. Respiratory parameters in CI-linked respiration. Mitochondrial respiratory parameters: state 3 (S3), state 4 induced by oligomycin (S4o), respiratory control index (RCI) and OXPHOS associated respiration $(\mathrm{P})$ using malate-pyruvate $(\mathrm{PM})$ as substrates. Data are mean $\pm \mathrm{SE}, n=6$. ** $p<0.01$ vs. sham, ${ }^{* * *} p<0.001$ vs. sham.

\section{$\mathbf{S}+\mathbf{R}$}

S3

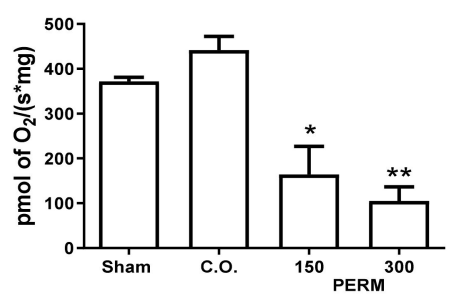

$\mathbf{P}$

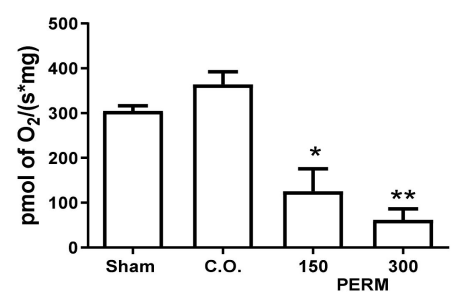

S4o

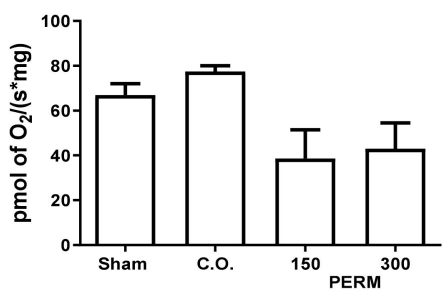

$\mathrm{RCI}$

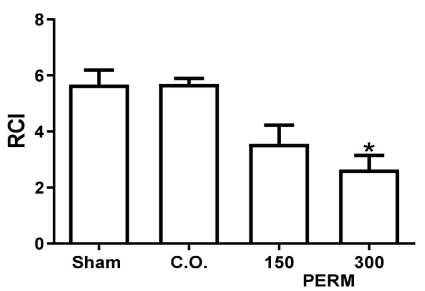

Figure 8. Respiratory parameters in CII-linked respiration. Mitochondrial respiratory parameters: state 3 (S3), state 4 induced by oligomycin (S4o), respiratory control index (RCI) and OXPHOS associated respiration $(\mathrm{P})$ using succinate plus rotenone $(\mathrm{S}+\mathrm{R})$ as substrates. Data are mean $\pm \mathrm{SE}$, $n=5-6$. ${ }^{*} p<0.05$ vs. sham group, ${ }^{* *} p<0.01$ vs. sham group.

\section{Discussion}

Permethrin (PERM) is a synthetic pyrethroid extensively used to control agricultural pests and disease vectors. Originally it was considered safe for humans and other animals due to its relatively low environmental toxicity in mammals. However, its neurotoxicity at high doses was soon described, and more recently, several side effects at chronic low doses 
have been reported [10]. The main route for human exposure is through contaminated food ingestion such as fruits, vegetables, or milk where it can accumulate.

The neurotoxicity of PERM at high doses has been widely studied [16-18,20-25]. It was reported to modify sodium channels in insects and mammals, leading to prolonged depolarization and repetitive discharges in presynaptic nerve fibers after a single stimulus $[14,15]$. This action is associated with tremor, hyperactivity, ataxia, convulsions, and in some cases, paralysis. PERM can also inhibit neuronal activity in hippocampal glutamatergic networks in a potent and concentration-dependent manner. PERM increases the risk of neuronal deficit and the development of neurodegeneration [43,44]. The neurodegenerative mechanisms associated with PERM have been studied. Among them, a detriment to the redox system is one of the most reported. Oxidative stress is a major determinant of neurodegeneration; a pro-oxidant state can trigger posttranscriptional modifications in the electron transport system. This increases reactive oxygen species (ROS) production and inhibits mitochondrial complex I. Thus, the deficit of antioxidant enzymes in different organs leads to protein, lipid and DNA damage $[25,28,31]$. However, there is little information about PERM neurotoxicity after exposure to low doses and for short periods. In this study, the effect of sublethal doses (1/10 and 1/30 of the LD50) and subacute PERM treatment was evaluated to identify their impact on the redox, bioenergetic and immune systems. Sub-chronic PERM exposure at both doses increased lipoperoxidation and carbonyl protein (PC) content, hallmarks of oxidative stress induced by the pesticide, in the central nervous system. Previous studies have shown reactive oxygen species generation, such as superoxide anion $\left(\mathrm{O}_{2}{ }^{\bullet-}\right)$ hydrogen peroxide $\left(\mathrm{H}_{2} \mathrm{O}_{2}\right)$, and nitric oxide $\left(\mathrm{NO}^{\bullet}\right)$ [45-48] in the brain due to PERM administration. In this regard, Falcioni and colleagues (2010) showed that sub-mitochondrial fractions of the striatum incubated with PERM showed decreased $\mathrm{O}_{2}{ }^{\bullet-}$ levels [49]. On the other hand, carbonyl groups (aldehydes and ketones) are produced on protein side chains (especially in Pro, Arg, Lys and Thr residues) when they are oxidized [50-52]. Alternatively, PC can result from an indirect mechanism that involves hydroxyl radical-mediated lipid oxidation. Polyunsaturated acyl chains of phospholipids or polyunsaturated fatty acids, such as arachidonic acid and linoleic acid, are highly susceptible to peroxidation and breakdown via non-enzymatic Hock cleavage, forming a variety of lipid-derived aldehydes and ketones [52]. Our results suggest that sub-chronic PERM exposure at sublethal doses induces oxidative stress in the rat brain even when using $1 / 10$ and $1 / 30$ of the reported LD50.

Enzymatic antioxidant mechanisms in the brain are important in maintaining the balance between pro-oxidant and antioxidant agents and to reduce damage due to oxidative stress. The antioxidant enzymes superoxide dismutase, catalase and glutathione peroxidase are the first to act in the presence of ROS. They catalyze the breakdown of the dismutase superoxide radical, hydrogen peroxides and hydroperoxides into harmless molecules $\left(\mathrm{H}_{2} \mathrm{O}_{2}\right.$ /alcohol and $\left.\mathrm{O}_{2}{ }^{\bullet-}\right)$ [53]. The enzymatic activity of SOD, CAT, GPx, GR and glutathione transferase (GST) were evaluated in the brain after sub-chronic and sublethal PERM exposure. After exposure, the activity of antioxidant enzymes increased, even with the lower dose used, in different regions of the nervous system; the highest increments were observed in SOD activity in all areas analyzed. Interestingly, the cerebellum showed major increases in the five enzymes studied.

Several studies have reported changes in the activity of SOD and GPx as well as a decay in GSH levels in the brain and peripherical blood after exposure to high doses of PERM $[49,54,55]$. Omotoso and co-workers explored SOD, CAT and GPx activities after PERM exposure in the prefrontal cortex, hippocampus and cerebellum correlated with lipoperoxidation using doses of 500 and $1000 \mathrm{mg} / \mathrm{kg}$ [56]. They found a general decrease in enzyme activity and a rise in lipoperoxidation levels. In our study, most of the antioxidant enzymes increased their activity in the four brain regions explored. However, when using $300 \mathrm{mg} / \mathrm{kg}$, some enzymes reduced their activity or did not show changes, especially in the prefrontal cortex (Table 3). Moreover, macromolecular markers of oxidative stress damage such as lipoperoxidation increased in all brain areas and mainly in the hemispheres and medulla, while protein carbonylation showed a 
major increase in the prefrontal cortex. Considering all the data, PERM exposure could impair the enzymatic antioxidant system in a dose-dependent manner. Low doses may increase the activity of antioxidant enzymes, while high doses inhibit them. This change in the redox state can be considered to cause neuroinflammation.

On the other hand, lipoperoxidation and protein carbonylation have been linked to cell death. Our results showed that the hemisphere containing the cerebral cortex (parietal, entorhinal and occipital) and internal structures such as the hypothalamus and hippocampus is highly susceptible to oxidative damage. Similarly, the prefrontal cortex is also vulnerable to oxidative stress that could be generated by low PERM doses.

PERM increased ROS levels, which can trigger a cascade of molecular and transcriptional events. These include the production of proinflammatory cytokines from local microglia and infiltrative neutrophils, monocytes and lymphocytes [57-59]. Microglia are the main source of several cytokines, including interleukin-1 $\beta$ (IL-1 $\beta$ ), tumor necrosis factor alpha (TNF- $\alpha$ ) and interleukin-6 (IL-6) [60]. This is the first report of inflammatory markers (IL-1 $\beta$, IL- 6 and TNF- $\alpha$ gene expression) in various regions of the brain (cerebellum, medulla, cerebral cortex and hemispheres) after acute exposure to low PERM concentrations ( 150 or $300 \mathrm{mg} / \mathrm{kg}$ ). Our results showed a significant increase in the expression of the three cytokines, mainly with the highest dose used. These pro-inflammatory cytokines participate in different processes such as neurogenesis, neurotransmission, cell proliferation and neuronal excitability [61-64].

Exposure to degenerated neurons, oxidized proteins, glycated products or lipid peroxidation induces a proinflammatory state in the adult brain. It has been demonstrated that high ROS levels increase IL- $1 \beta$ levels in hippocampal cultures, while antioxidant administration decreases their expression $[65,66]$. In turn, IL-1 $\beta$ significantly decreases cell proliferation in the hippocampus [67]. Additionally, PERM exposure induces a proinflammatory state that includes IL-6 production [68]. In the brain, IL-6 is produced in activated microglial cells and reduces proliferation, differentiation and survival of neuronal precursors in the dentate gyrus [69]. It also alters synaptic protein levels in the hippocampus [70]. Finally, results from studies in animal models showed that high levels of IL-6 can damage cognitive functions such as memory and learning [71].

TNF- $\alpha$ has been reported to have pro-and anti-neurogenic properties, depending on the concentration, experimental model and cell-derived regions [72-74]. In this sense, our results showed increased TNF- $\alpha$ mRNA expression at $300 \mathrm{mg} / \mathrm{kg}$ in the four brain regions evaluated, but no changes were detected at the $150 \mathrm{mg} / \mathrm{kg}$ concentration. In addition, it has been shown that PERM may directly activate microglial cells through its interaction with voltage-gated sodium channels (VGSC). This may contribute to excessive accumulation of intracellular $\mathrm{Na}^{+}$that depolarizes the cells to release TNF- $\alpha$ [75]. Interestingly, this proinflammatory cytokine can alter the balance of excitatory to inhibitory neurotransmission, inducing a higher synaptic excitatory/inhibitory ratio [76]. Additionally, acute low doses of PERM induce neuronal degeneration in the brain [25] and increase spontaneous glutamate release from hippocampal neurons [77].

The most important increases in the analyzed cytokines were registered in cerebellum and medulla, suggesting a dysfunction of the normal physiology of these areas that may be related to ROS generated by low PERM exposure. Baek and co-workers concluded that the vulnerability to oxidative stress in the brain is region-specific and dependent on the local iron-catalyzed Fenton reaction or the Haber-Weiss reaction [78]. Other authors report that brain areas such as the cortex, hypothalamus, hippocampus and striatum are more susceptible to oxidative damage in comparison to the cerebellum. In this study, the qualitative histological analysis showed more damage in the hippocampus due to the administration of both doses of permethrin. Some of these changes, including the death or decrease in the number of neurons, were observed mainly in the dentate gyrus area. Abdel-Rahman and co-workers reported neuronal death induced by pesticides in a model of Gulf-War syndrome [79]. Parihar associated hippocampal pathology with decreased neurogenesis, loss of principal neurons, and inflammation as well as a dysfunction of mood 
and cognition in a model of Gulf-War illness using rats [28]. Our data showed that PERM exposure can compromise hippocampal structural integrity, which in turn could affect vital neurological functions of this brain region, causing alterations such as motor deficits or dysfunctions in learning and memory, as has been described by Omotoso and co-workers (2020) [56] and Abdel-Rahman and co-workers (2001) [79]. However, a more detailed study of the changes induced by PERM exposure is needed to better understand the effects of this pyrethroid on brain integrity.

Some studies report a relationship between oxidative stress and mitochondrial abnormalities in the brain. Moreover, it has been proposed that pyrethroids trigger an impairment of mitochondrial function, increasing ROS production. Similarly, mitochondria could be vulnerable to the deleterious effects of $\mathrm{Ca}_{2}{ }^{+}$ions. The evaluation of mitochondrial bioenergetics parameters in the brain showed that PERM strongly decouples oxidative phosphorylation with the higher dose. This impairment may be associated with a reduction in the capacity for ATP synthesis, since there was an important decrease in $p$ values and RCI independently of the substrate used (Figures 7 and $8 c, d$ ). Furthermore, several models have demonstrated that an increase in oxidative stress can decrease the activity of ATP synthase and mitochondrial complexes [38,80]. Additionally, mitochondrial bioenergetic alterations can favor other mechanisms such as inflammation, fibrosis, and cell death and are involved in neurodegenerative disorders such as cancer, pulmonary diseases, diabetes, and cardiovascular diseases [81,82].

Complex I of the electron transport chain may be the most sensitive to PERM, and with both concentrations the same effect was observed. Our results agree with Gassner and coworkers [83], who reported a high susceptibility of complex I to the deleterious effects of permethrin in the rat liver. However, complex I was not the only affected complex, since state 3 was affected by PERM exposure even in the presence of rotenone. This suggests that PERM impairs other respiratory complexes.

Proton leakage was also analyzed by measuring $\mathrm{O}_{2}$ consumption under non-phosphorylating conditions (state 4o). The results did not show a statistically significant effect, but there was a tendency towards reduced oxygen consumption in hippocampal mitochondria isolated from animals treated with PERM. Oxidative phosphorylation produces superoxide and is the main source of ROS. Mitochondrial superoxide production is closely dependent on $\Delta p$, and Brand proposed that proton leakage could minimize oxidative damage by modulating superoxide production, where oxidative stress is considered a detrimental condition for normal brain functioning. Specifically, ROS increase the susceptibility to neuronal damage, and the variability in the data for state 40 could be related to differences in cell damage observed between the different hippocampal areas [84].

\section{Conclusions}

The results obtained in this study suggest that subacute PERM exposure at low doses increases ROS production, induces an imbalance in the enzymatic antioxidant system and increases the gene expression of pro-inflammatory interleukins in different brain areas. These changes could lead to cell damage mediated by mitochondrial functional impairment. These results allowed us to better understand the complex mechanism involved in the toxic effects induced by PERM. Subsequent experiments will explore minimal doses and determine the timing of the changes that we described in this study.

Author Contributions: Conceptualization, T.G.L.-A., E.C.-U.; methodology, T.G.L.-A., E.C.-U., F.E.R., and M.E.H.; investigation, T.G.L.-A., E.C.-U., F.E.-R., A.V.-C., and L.C.-A., M.E.H., L.N., O.E.A.-T., O.N.M.-C., V.S.-V., N.C.-R., L.G.-R., A.P.-T., E.P.-C., V.R.-M., J.P.-C., D.M.-F., and C.d.R.L.-S.; formal analysis, A.P.-T., D.M.-F., J.P.-C., and E.C.-U.; writing-original draft preparation and editing, A.V.-C., L.C.-A., and E.C.-U.; project administration, E.C.-U.; funding acquisition, E.C.-U., F.E.-R., and L.N. All authors have read and agreed to the published version of the manuscript.

Funding: We appreciate the financial support received from Protocol 060/2018, Program E022, National Institute of Pediatrics, Number INP 060/2018. F.E.-R., A.V.-C., L.C.-A., M.E.H., J.P.-C., L.N., O.N.M.-C., A.P.-T., D.M.-F., V.S.-V., N.C.-R., C.d.R.L.-S., and E.C.-U. are SNI-CONACyT Fellows. 
Institutional Review Board Statement: Experimental procedures are part of project 060/2018, approved by the Institutional Committees of Research and of Laboratory Animal Use and Care. Institutional Committee of Research is registered at the NIH Office for Human Research Protection (http:/ / ohrp.cit.nih. gov/search (accessed on 31 July 2020).) with number IRB00008064 on 16 January 2019.

Informed Consent Statement: Not applicable.

Data Availability Statement: Data is contained within the article.

Acknowledgments: We thank Sergio Humberto Larios-Godínez, Wilfrido Fernando Guerrero Uriarte and Chemist Manuel Rodríguez-Sotelo.

Conflicts of Interest: The authors declare that there is no conflict of interest regarding the publication of this paper.

\section{References}

1. Cao, F.; Souders, C.L., II; Perez-Rodriguez, V.; Martyniuk, C.J. Elucidating Conserved Transcriptional Networks Underlying Pesticide Exposure and Parkinson's Disease: A Focus on Chemicals of Epidemiological Relevance. Front. Genet. 2018, 9, 701. [CrossRef] [PubMed]

2. Hanke, W.; Jurewicz, J. The risk of adverse reproductive and developmental disorders due to occupational pesticide exposure: An overview of current epidemiological evidence. Int. J. Occup. Med. Environ. Health 2004, 17, 223-243.

3. Valcke, M.; Levasseur, M.E.; Soares da Silva, A.; Wesseling, C. Pesticide exposures and chronic kidney disease of unknown etiology: An epidemiologic review. Environ. Health 2017, 16, 49. [CrossRef] [PubMed]

4. Choudri, B.S.; Charabi, Y.; Baawain, M.; Ahmed, M. Effects of Pollution on Freshwater Organisms. Water Environ. Res. 2017, 89, 1676-1703. [CrossRef]

5. Del Prado-Lu, J.L. Insecticide residues in soil, water, and eggplant fruits and farmers' health effects due to exposure to pesticides. Environ. Health Prev. Med. 2015, 20, 53-62. [CrossRef]

6. Lu, J.L. Analysis of Trends of the Types of Pesticide Used, Residues and Related Factors among Farmers in the Largest Vegetable Producing Area in the Philippines. J. Rural Med. 2010, 5, 184-189. [CrossRef] [PubMed]

7. Pirsaheb, M.; Limoee, M.; Namdari, F.; Khamutian, R. Organochlorine pesticides residue in breast milk: A systematic review. Med. J. Islam. Repub. Iran. 2015, 29, 228.

8. Williams, M.K.; Rundle, A.; Holmes, D.; Reyes, M.; Hoepner, L.A.; Barr, D.B.; Camann, D.E.; Perera, F.P.; Whyatt, R.M. Changes in pest infestation levels, self-reported pesticide use, and permethrin exposure during pregnancy after the 2000-2001 U.S. Environmental Protection Agency restriction of organophosphates. Environ. Health Perspect. 2008, 116, 1681-1688. [CrossRef] [PubMed]

9. Breckenridge, C.B.; Holden, L.; Sturgess, N.; Weiner, M.; Sheets, L.; Sargent, D.; Soderlund, D.M.; Choi, J.S.; Symington, S.; Clark, J.M.; et al. Evidence for a separate mechanism of toxicity for the Type I and the Type II pyrethroid insecticides. Neurotoxicology 2009, 30 (Suppl. 1), S17-S31. [CrossRef]

10. Chrustek, A.; Holynska-Iwan, I.; Dziembowska, I.; Bogusiewicz, J.; Wroblewski, M.; Cwynar, A.; Olszewska-Slonina, D. Current Research on the Safety of Pyrethroids Used as Insecticides. Medicina 2018, 54, 61. [CrossRef]

11. Horton, M.K.; Jacobson, J.B.; McKelvey, W.; Holmes, D.; Fincher, B.; Quantano, A.; Diaz, B.P.; Shabbazz, F.; Shepard, P.; Rundle, A.; et al. Characterization of residential pest control products used in inner city communities in New York City. J. Expo. Sci. Environ. Epidemiol. 2011, 21, 291-301. [CrossRef]

12. Power, L.E.; Sudakin, D.L. Pyrethrin and pyrethroid exposures in the United States: A longitudinal analysis of incidents reported to poison centers. J. Med. Toxicol. 2007, 3, 94-99. [CrossRef]

13. Bradberry, S.M.; Cage, S.A.; Proudfoot, A.T.; Vale, J.A. Poisoning due to pyrethroids. Toxicol. Rev. 2005, 24, 93-106. [CrossRef] [PubMed]

14. Costa, L.G. The neurotoxicity of organochlorine and pyrethroid pesticides. Handb. Clin. Neurol. 2015, 131, 135-148. [CrossRef]

15. Soderlund, D.M. Molecular mechanisms of pyrethroid insecticide neurotoxicity: Recent advances. Arch. Toxicol. 2012, 86, 165-181. [CrossRef]

16. Gunning, K.; Kiraly, B.; Pippitt, K. Lice and Scabies: Treatment Update. Am. Fam. Phys. 2019, 99, 635-642.

17. Gunning, K.; Pippitt, K.; Kiraly, B.; Sayler, M. Pediculosis and scabies: Treatment update. Am. Fam. Phys. 2012, 86, 535-541.

18. Londono-Renteria, B.; Patel, J.C.; Vaughn, M.; Funkhauser, S.; Ponnusamy, L.; Grippin, C.; Jameson, S.B.; Apperson, C.; Mores, C.N.; Wesson, D.M.; et al. Long-Lasting Permethrin-Impregnated Clothing Protects Against Mosquito Bites in Outdoor Workers. Am. J. Trop. Med. Hyg. 2015, 93, 869-874. [CrossRef] [PubMed]

19. Salavastru, C.M.; Chosidow, O.; Boffa, M.J.; Janier, M.; Tiplica, G.S. European guideline for the management of scabies. J. Eur. Acad. Dermatol. Venereol. 2017, 31, 1248-1253. [CrossRef] [PubMed]

20. Sullivan, K.M.; Poffley, A.; Funkhouser, S.; Driver, J.; Ross, J.; Ospina, M.; Calafat, A.M.; Beard, C.B.; White, A.; Balanay, J.A.; et al. Bioabsorption and effectiveness of long-lasting permethrin-treated uniforms over three months among North Carolina outdoor workers. Parasit Vectors 2019, 12, 52. [CrossRef] 
21. Holynska-Iwan, I.; Szewczyk-Golec, K. Pyrethroids: How They Affect Human and Animal Health? Medicina 2020, 56, 582. [CrossRef] [PubMed]

22. Joshi, U.; Pearson, A.; Evans, J.E.; Langlois, H.; Saltiel, N.; Ojo, J.; Klimas, N.; Sullivan, K.; Keegan, A.P.; Oberlin, S.; et al. A permethrin metabolite is associated with adaptive immune responses in Gulf War Illness. Brain Behav. Immun. 2019, 81, 545-559. [CrossRef]

23. Shearer, J.J.; Beane Freeman, L.E.; Liu, D.; Andreotti, G.; Hamilton, J.; Happel, J.; Lynch, C.F.; Alavanja, M.C.; Hofmann, J.N. Longitudinal investigation of haematological alterations among permethrin-exposed pesticide applicators in the Biomarkers of Exposure and Effect in Agriculture study. Occup. Environ. Med. 2019, 76, 467-470. [CrossRef]

24. Sundaramoorthy, R.; Velusamy, Y.; Balaji, A.P.; Mukherjee, A.; Chandrasekaran, N. Comparative cytotoxic and genotoxic effects of permethrin and its nanometric form on human erythrocytes and lymphocytes in vitro. Chem. Biol. Interact. 2016, 257, 119-124. [CrossRef]

25. Wang, X.; Martinez, M.A.; Dai, M.; Chen, D.; Ares, I.; Romero, A.; Castellano, V.; Martinez, M.; Rodriguez, J.L.; MartinezLarranaga, M.R.; et al. Permethrin-induced oxidative stress and toxicity and metabolism. A review. Environ. Res. 2016, 149, 86-104. [CrossRef] [PubMed]

26. Carpenter, J.M.; Gordon, H.E.; Ludwig, H.D.; Wagner, J.J.; Harn, D.A.; Norberg, T.; Filipov, N.M. Neurochemical and neuroinflammatory perturbations in two Gulf War Illness models: Modulation by the immunotherapeutic LNFPIII. Neurotoxicology 2020, 77, 40-50. [CrossRef]

27. Kodali, M.; Hattiangady, B.; Shetty, G.A.; Bates, A.; Shuai, B.; Shetty, A.K. Curcumin treatment leads to better cognitive and mood function in a model of Gulf War Illness with enhanced neurogenesis, and alleviation of inflammation and mitochondrial dysfunction in the hippocampus. Brain Behav. Immun. 2018, 69, 499-514. [CrossRef] [PubMed]

28. Parihar, V.K.; Hattiangady, B.; Shuai, B.; Shetty, A.K. Mood and memory deficits in a model of Gulf War illness are linked with reduced neurogenesis, partial neuron loss, and mild inflammation in the hippocampus. Neuropsychopharmacology 2013, 38, 2348-2362. [CrossRef]

29. Parkitny, L.; Middleton, S.; Baker, K.; Younger, J. Evidence for abnormal cytokine expression in Gulf War Illness: A preliminary analysis of daily immune monitoring data. BMC Immunol. 2015, 16, 57. [CrossRef]

30. Shetty, G.A.; Hattiangady, B.; Upadhya, D.; Bates, A.; Attaluri, S.; Shuai, B.; Kodali, M.; Shetty, A.K. Chronic Oxidative Stress, Mitochondrial Dysfunction, Nrf2 Activation and Inflammation in the Hippocampus Accompany Heightened Systemic Inflammation and Oxidative Stress in an Animal Model of Gulf War Illness. Front. Mol. Neurosci. 2017, 10, 182. [CrossRef]

31. Nunes, M.E.M.; Schimith, L.E.; da Costa-Silva, D.G.; Lopes, A.R.; Leandro, L.P.; Martins, I.K.; de Mello, R.S.; Hartmann, D.D.; de Carvalho, N.R.; da Rosa, P.C.; et al. Acute Exposure to Permethrin Modulates Behavioral Functions, Redox, and Bioenergetics Parameters and Induces DNA Damage and Cell Death in Larval Zebrafish. Oxid. Med. Cell. Longev. 2019, $2019,9149203$. [CrossRef]

32. Cantalamessa, F. Acute toxicity of two pyrethroids, permethrin, and cypermethrin in neonatal and adult rats. Arch. Toxicol. 1993, 67, 510-513. [CrossRef]

33. Lowry, O.H.; Rosebrough, N.J.; Farr, A.L.; Randall, R.J. Protein measurement with the Folin phenol reagent. J. Biol. Chem. 1951, 193, 265-275. [CrossRef]

34. Coballase-Urrutia, E.; Pedraza-Chaverri, J.; Camacho-Carranza, R.; Cardenas-Rodriguez, N.; Huerta-Gertrudis, B.; MedinaCampos, O.N.; Mendoza-Cruz, M.; Delgado-Lamas, G.; Espinosa-Aguirre, J.J. Antioxidant activity of Heterotheca inuloides extracts and of some of its metabolites. Toxicology 2010, 276, 41-48. [CrossRef] [PubMed]

35. Coballase-Urrutia, E.; Pedraza-Chaverri, J.; Cardenas-Rodriguez, N.; Huerta-Gertrudis, B.; Garcia-Cruz, M.E.; Montesinos-Correa, H.; Sanchez-Gonzalez, D.J.; Camacho-Carranza, R.; Espinosa-Aguirre, J.J. Acetonic and Methanolic Extracts of Heterotheca inuloides, and Quercetin, Decrease CCl(4)-Oxidative Stress in Several Rat Tissues. Evid.-Based Complement. Alternat. Med. 2013, 2013, 659165. [CrossRef] [PubMed]

36. Carmona-Aparicio, L.; Cardenas-Rodriguez, N.; Delgado-Lamas, G.; Pedraza-Chaverri, J.; Montesinos-Correa, H.; RiveraEspinosa, L.; Torres-Espindola, L.M.; Hernandez, M.E.; Lopez-Aceves, T.; Perez-Lozano, D.L.; et al. Dose-Dependent Behavioral and Antioxidant Effects of Quercetin and Methanolic and Acetonic Extracts from Heterotheca inuloides on Several Rat Tissues following Kainic Acid-Induced Status Epilepticus. Oxid. Med. Cell. Longev. 2019, 2019, 5287507. [CrossRef]

37. Rojas-Morales, P.; Leon-Contreras, J.C.; Aparicio-Trejo, O.E.; Reyes-Ocampo, J.G.; Medina-Campos, O.N.; Jimenez-Osorio, A.S.; Gonzalez-Reyes, S.; Marquina-Castillo, B.; Hernandez-Pando, R.; Barrera-Oviedo, D.; et al. Fasting reduces oxidative stress, mitochondrial dysfunction and fibrosis induced by renal ischemia-reperfusion injury. Free Radic. Biol. Med. 2019, $135,60-67$. [CrossRef]

38. Aparicio-Trejo, O.E.; Reyes-Fermin, L.M.; Briones-Herrera, A.; Tapia, E.; Leon-Contreras, J.C.; Hernandez-Pando, R.; SanchezLozada, L.G.; Pedraza-Chaverri, J. Protective effects of N-acetyl-cysteine in mitochondria bioenergetics, oxidative stress, dynamics and S-glutathionylation alterations in acute kidney damage induced by folic acid. Free Radic. Biol. Med. 2019, 130, 379-396. [CrossRef] [PubMed]

39. Bozolla, J.J.; Russell, L.D. (Eds.) Specimen preparation for transmission electron microscopy. In Electron Microscopy.Principles and Techniques for Biologists, 2nd ed.; Jones and Bartlett Publishers, Inc.: Burlington, MA, USA, 1999.

40. Paxinos, G.; Watson, C. The Rat Brain in Stereotaxic Coordinates, 4th ed.; Academic Press: Cambridge, MA, USA, 1998. 
41. Prophet, E.B.; Mills, B.; Arrington, J.B.; Sobin, L.H. (Eds.) Neuropathological histotechnology. In Laboratory Methods in Histotechnology; Armed Forces Institute of Pathology: Washington, DC, USA, 1992; pp. 94-95.

42. Kumar, V.; Abbas, A.K.; Fausto, N.; Aster, J.C. Cellular responses to stress and toxic insults: Adaptation, injury, and death. In Robbins and Cotran: Pathological Basis of Diseases, 8th ed.; Saunders Elsevier: Philadelphia, PA, USA, 2010; pp. 3-42.

43. Bordoni, L.; Nasuti, C.; Fedeli, D.; Galeazzi, R.; Laudadio, E.; Massaccesi, L.; Lopez-Rodas, G.; Gabbianelli, R. Early impairment of epigenetic pattern in neurodegeneration: Additional mechanisms behind pyrethroid toxicity. Exp. Gerontol. 2019, 124, 110629. [CrossRef]

44. Meyer, D.A.; Carter, J.M.; Johnstone, A.F.; Shafer, T.J. Pyrethroid modulation of spontaneous neuronal excitability and neurotransmission in hippocampal neurons in culture. Neurotoxicology 2008, 29, 213-225. [CrossRef]

45. Carloni, M.; Nasuti, C.; Fedeli, D.; Montani, M.; Amici, A.; Vadhana, M.S.; Gabbianelli, R. The impact of early life permethrin exposure on development of neurodegeneration in adulthood. Exp. Gerontol. 2012, 47, 60-66. [CrossRef]

46. Fedeli, D.; Carloni, M.; Nasuti, C.; Gambini, A.; Scocco, V.; Gabbianelli, R. Early life permethrin exposure leads to hypervitaminosis D, nitric oxide and catecholamines impairment. Pestic. Biochem. Physiol. 2013, 107, 93-97. [CrossRef]

47. Gabbianelli, R.; Falcioni, M.L.; Nasuti, C.; Cantalamessa, F.; Imada, I.; Inoue, M. Effect of permethrin insecticide on rat polymorphonuclear neutrophils. Chem. Biol. Interact. 2009, 182, 245-252. [CrossRef] [PubMed]

48. Nasuti, C.; Carloni, M.; Fedeli, D.; Di Stefano, A.; Marinelli, L.; Cerasa, L.S.; Meda, C.; Maggi, A.; Gabbianelli, R. Effect of 17beta-estradiol on striatal dopaminergic transmission induced by permethrin in early childhood rats. Chemosphere 2014, 112, 496-502. [CrossRef]

49. Falcioni, M.L.; Nasuti, C.; Bergamini, C.; Fato, R.; Lenaz, G.; Gabbianelli, R. The primary role of glutathione against nuclear DNA damage of striatum induced by permethrin in rats. Neuroscience 2010, 168, 2-10. [CrossRef]

50. Davies, M.J. Protein oxidation and peroxidation. Biochem. J. 2016, 473, 805-825. [CrossRef] [PubMed]

51. Radi, R. Protein tyrosine nitration: Biochemical mechanisms and structural basis of functional effects. Acc. Chem. Res. 2013, 46, 550-559. [CrossRef] [PubMed]

52. Schneider, C.; Tallman, K.A.; Porter, N.A.; Brash, A.R. Two distinct pathways of formation of 4-hydroxynonenal. Mechanisms of nonenzymatic transformation of the 9- and 13-hydroperoxides of linoleic acid to 4-hydroxyalkenals. J. Biol. Chem. 2001, 276, 20831-20838. [CrossRef]

53. Ighodaro, O.M.; Akinloye, O.A. First line defence antioxidants-superoxide dismutase (SOD), catalase (CAT) and glutathione peroxidase (GPX): Their fundamental role in the entire antioxidant defence grid. Alex. J. Med. 2018, 54, 287-293. [CrossRef]

54. Nasuti, C.; Gabbianelli, R.; Falcioni, M.L.; Di Stefano, A.; Sozio, P.; Cantalamessa, F. Dopaminergic system modulation, behavioral changes, and oxidative stress after neonatal administration of pyrethroids. Toxicology 2007, 229, 194-205. [CrossRef] [PubMed]

55. Rosita, G.; Manuel, C.; Franco, M.; Cinzia, N.; Donatella, F.; Emiliano, L.; Luca, M.; Roberta, G. Permethrin and its metabolites affect $\mathrm{Cu} / \mathrm{Zn}$ superoxide conformation: Fluorescence and in silico evidences. Mol. Biosyst. 2015, 11, 208-217. [CrossRef]

56. Omotoso, G.; Oloyede, O.; Lawal, S.; Gbadamosi, I.; Mutholib, N.; Abdulsalam, F.; Bature, A.; Babalola, A.; Ayeni, B.; Amedu, N. Permethrin exposure affects neurobehavior and cellular characterization in rats' brain. Environ. Anal. Health Toxicol. 2020, 35, e2020022. [CrossRef]

57. Martinon, F. Signaling by ROS drives inflammasome activation. Eur. J. Immunol. 2010, 40, 616-619. [CrossRef] [PubMed]

58. Ray, P.D.; Huang, B.W.; Tsuji, Y. Reactive oxygen species (ROS) homeostasis and redox regulation in cellular signaling. Cell. Signal. 2012, 24, 981-990. [CrossRef]

59. Wolf, S.A.; Boddeke, H.W.; Kettenmann, H. Microglia in Physiology and Disease. Annu. Rev. Physiol. 2017, 79, 619-643. [CrossRef] [PubMed]

60. Graeber, M.B.; Li, W.; Rodriguez, M.L. Role of microglia in CNS inflammation. FEBS Lett. 2011, 585, 3798-3805. [CrossRef]

61. Fogal, B.; Hewett, S.J. Interleukin-1beta: A bridge between inflammation and excitotoxicity? J. Neurochem. 2008, 106, 1-23. [CrossRef]

62. Rizzo, F.R.; Musella, A.; De Vito, F.; Fresegna, D.; Bullitta, S.; Vanni, V.; Guadalupi, L.; Stampanoni Bassi, M.; Buttari, F.; Mandolesi, G.; et al. Tumor Necrosis Factor and Interleukin-1beta Modulate Synaptic Plasticity during Neuroinflammation. Neural Plast. 2018, 2018, 8430123. [CrossRef]

63. Sierra, A.; Beccari, S.; Diaz-Aparicio, I.; Encinas, J.M.; Comeau, S.; Tremblay, M.E. Surveillance, phagocytosis, and inflammation: How never-resting microglia influence adult hippocampal neurogenesis. Neural Plast. 2014, 2014, 610343. [CrossRef] [PubMed]

64. Widera, D.; Mikenberg, I.; Elvers, M.; Kaltschmidt, C.; Kaltschmidt, B. Tumor necrosis factor alpha triggers proliferation of adult neural stem cells via IKK/NF-kappaB signaling. BMC Neurosci. 2006, 7, 64. [CrossRef]

65. Bernardino, L.; Xapelli, S.; Silva, A.P.; Jakobsen, B.; Poulsen, F.R.; Oliveira, C.R.; Vezzani, A.; Malva, J.O.; Zimmer, J. Modulator effects of interleukin-1beta and tumor necrosis factor-alpha on AMPA-induced excitotoxicity in mouse organotypic hippocampal slice cultures. J. Neurosci. 2005, 25, 6734-6744. [CrossRef] [PubMed]

66. Li, Y.; Li, J.; Li, S.; Li, Y.; Wang, X.; Liu, B.; Fu, Q.; Ma, S. Curcumin attenuates glutamate neurotoxicity in the hippocampus by suppression of ER stress-associated TXNIP/NLRP3 inflammasome activation in a manner dependent on AMPK. Toxicol. Appl. Pharmacol. 2015, 286, 53-63. [CrossRef] [PubMed]

67. Zhang, K.; Xu, H.; Cao, L.; Li, K.; Huang, Q. Interleukin-1beta inhibits the differentiation of hippocampal neural precursor cells into serotonergic neurons. Brain Res. 2013, 1490, 193-201. [CrossRef] [PubMed] 
68. Neta, G.; Goldman, L.R.; Barr, D.; Apelberg, B.J.; Witter, F.R.; Halden, R.U. Fetal exposure to chlordane and permethrin mixtures in relation to inflammatory cytokines and birth outcomes. Environ. Sci. Technol. 2011, 45, 1680-1687. [CrossRef] [PubMed]

69. Vallieres, L.; Campbell, I.L.; Gage, F.H.; Sawchenko, P.E. Reduced hippocampal neurogenesis in adult transgenic mice with chronic astrocytic production of interleukin-6. J. Neurosci. 2002, 22, 486-492. [CrossRef]

70. Gruol, D.L. IL-6 regulation of synaptic function in the CNS. Neuropharmacology 2015, 96, 42-54. [CrossRef]

71. Trapero, I.; Cauli, O. Interleukin 6 and cognitive dysfunction. Metab. Brain Dis. 2014, 29, 593-608. [CrossRef]

72. Ben-Hur, T.; Ben-Menachem, O.; Furer, V.; Einstein, O.; Mizrachi-Kol, R.; Grigoriadis, N. Effects of proinflammatory cytokines on the growth, fate, and motility of multipotential neural precursor cells. Mol. Cell. Neurosci. 2003, 24, 623-631. [CrossRef]

73. Iosif, R.E.; Ahlenius, H.; Ekdahl, C.T.; Darsalia, V.; Thored, P.; Jovinge, S.; Kokaia, Z.; Lindvall, O. Suppression of stroke-induced progenitor proliferation in adult subventricular zone by tumor necrosis factor receptor 1. J. Cereb. Blood Flow Metab. 2008, 28, 1574-1587. [CrossRef]

74. Wu, J.P.; Kuo, J.S.; Liu, Y.L.; Tzeng, S.F. Tumor necrosis factor-alpha modulates the proliferation of neural progenitors in the subventricular/ventricular zone of adult rat brain. Neurosci. Lett. 2000, 292, 203-206. [CrossRef]

75. Hossain, M.M.; Liu, J.; Richardson, J.R. Pyrethroid Insecticides Directly Activate Microglia Through Interaction With VoltageGated Sodium Channels. Toxicol. Sci. 2017, 155, 112-123. [CrossRef]

76. Olmos, G.; Llado, J. Tumor necrosis factor alpha: A link between neuroinflammation and excitotoxicity. Mediators Inflamm. 2014, 2014, 861231. [CrossRef]

77. Meyer, D.A.; Shafer, T.J. Permethrin, but not deltamethrin, increases spontaneous glutamate release from hippocampal neurons in culture. Neurotoxicology 2006, 27, 594-603. [CrossRef]

78. Baek, B.S.; Kwon, H.J.; Lee, K.H.; Yoo, M.A.; Kim, K.W.; Ikeno, Y.; Yu, B.P.; Chung, H.Y. Regional difference of ROS generation, lipid peroxidation, and antioxidant enzyme activity in rat brain and their dietary modulation. Arch. Pharm. Res. 1999, 22, 361-366. [CrossRef]

79. Abdel-Rahman, A.; Shetty, A.K.; Abou-Donia, M.B. Subchronic dermal application of N,N-diethyl m-toluamide (DEET) and permethrin to adult rats, alone or in combination, causes diffuse neuronal cell death and cytoskeletal abnormalities in the cerebral cortex and the hippocampus, and Purkinje neuron loss in the cerebellum. Exp. Neurol. 2001, 172, 153-171. [CrossRef] [PubMed]

80. Mailloux, R.J.; Jin, X.; Willmore, W.G. Redox regulation of mitochondrial function with emphasis on cysteine oxidation reactions Redox. Biol. 2014, 2, 123-139. [CrossRef]

81. Chen, J.F.; Liu, H.; Ni, H.F.; Lv, L.L.; Zhang, M.H.; Zhang, A.H.; Tang, R.N.; Chen, P.S.; Liu, B.C. Improved mitochondrial function underlies the protective effect of pirfenidone against tubulointerstitial fibrosis in 5/6 nephrectomized rats. PLoS ONE 2013, 8, e83593. [CrossRef]

82. Patergnani, S.; Bouhamida, E.; Leo, S.; Pinton, P.; Rimessi, A. Mitochondrial Oxidative Stress and "Mito-Inflammation": Actors in the Diseases. Biomedicines 2021, 9, 216. [CrossRef] [PubMed]

83. Gassner, B.; Wuthrich, A.; Scholtysik, G.; Solioz, M. The pyrethroids permethrin and cyhalothrin are potent inhibitors of the mitochondrial complex I. J. Pharmacol. Exp. Ther. 1997, 281, 855-860.

84. Brand, M.D. Mitochondrial generation of superoxide and hydrogen peroxide as the source of mitochondrial redox signaling. Free Radic. Biol. Med. 2016, 100, 14-31. [CrossRef] 